$10-8-2021$

\title{
Pinpointing Patterns of Violence: A Comparative Genocide Studies Approach to Violence Escalation in the Ukrainian Holodomor
}

Kristina Hook

Kennesaw State University

Follow this and additional works at: https://digitalcommons.usf.edu/gsp

\section{Recommended Citation}

Hook, Kristina (2021) "Pinpointing Patterns of Violence: A Comparative Genocide Studies Approach to Violence Escalation in the Ukrainian Holodomor," Genocide Studies and Prevention: An International Journal: Vol. 15: Iss. 2: 10-36.

DOI:

https://doi.org/10.5038/1911-9933.15.2.1809

Available at: https://digitalcommons.usf.edu/gsp/vol15/iss2/5

This Articles is brought to you for free and open access by the Open Access Journals at Digital Commons @ University of South Florida. It has been accepted for inclusion in Genocide Studies and Prevention: An International Journal by an authorized editor of Digital Commons @ University of South Florida. For more information, please contact digitalcommons@usf.edu. 


\section{Pinpointing Patterns of Violence: A Comparative Genocide Studies Approach to Violence Escalation in the Ukrainian Holodomor}

\section{Acknowledgements}

I am appreciative of Drs. Ernesto Verdeja, Rahul Oka, George Lopez, Vania Smith-Oka, Agustin Fuentes, and Serhii Plokhii for their helpful feedback which strengthened earlier drafts this manuscript. This article was also improved by the University of Notre Dame's Kroc Institute for International Peace Studies writing seminar and the Holodomor Research and Education Consortium's research brownbag, and I would like to thank each of these participants for their comments and suggestions. This article greatly benefitted from research and translational assistance from Oksana Yanchuk. Data collection for this article was funded by the National Science Foundation's Graduate Research Fellowship Program (NSF-GRFP), USAID Research and Innovation Fellowship program, Kroc Institute for International Peace Studies, Notre Dame Anthropology Department, Kellogg Institute for International Studies, Nanovic Institute for European Studies, the Holodomor Research and Education Consortium, and a U.S. Fulbright scholarship. I am appreciative of each of these funding programs for making this research possible. Data collection for this article was funded by the National Science Foundation's Graduate Research Fellowship Program (NSFGRFP), USAID Research and Innovation Fellowship program, Kroc Institute for International Peace Studies, Notre Dame Anthropology Department, Nanovic Institute for European Studies, Kellogg Institute for International Studies, and a U.S. Fulbright scholarship. 


\title{
Pinpointing Patterns of Violence: A Comparative Genocide Studies Approach to Violence Escalation in the Ukrainian Holodomor
}

\author{
Kristina Hook \\ Kennesaw State University \\ Kennesaw, Georgia, U.S.A.
}

\section{Introduction}

For genocide prevention specialists, rapidly unfolding events and shifting violence patterns complicate efforts to understand, trace, and respond to this extreme social phenomenon. Devising policy-oriented frameworks structured enough to organize chaotic, complex events but flexible enough for cross-cultural variation requires analysts to thread the needle between speed and accuracy. Drawing from my experience in both genocide prevention policy and research, I suggest that answers to two key conceptual debates within comparative genocide studies are needed to advance genocide and mass atrocity analytic tools: 1) What are the core features that distinguish genocides from other forms of violence ${ }^{1}$ and 2) how can we trace genocidal patterns within larger processes of unfolding violence? ${ }^{2}$

To circumvent unproductive definitional arguments, some scholars have suggested methodologies that analyze large-scale violence (genocide and other) according to numerically based thresholds. ${ }^{3}$ Primarily quantitative, these methodologies represent the field's undeniable growth in epistemological sophistication, ${ }^{4}$ while answering certain aspects of the genocide puzzle. However, victim threshold-based methodologies are limited in their ability to incorporate cross-cultural variation and-relatedly-to guide the design of specific, contextually tailored violence interventions in real-time. To address this need, I operationalize other scholars' conceptual innovations to present a methodology grounded in two areas of scholarly consensus regarding what separates genocides from other large-scale violence: who is targeted (intended target) and for what purpose (intended purpose). ${ }^{5}$ In doing so, I demonstrate that the dynamics of genocidal and other violence can be mapped as they unfold, including as their characteristics evolve in the context of their broader occurrence.

Current violence in Nagorno-Karabakh and eastern Ukraine underscores the relationship between historical events and modern victims, with Joseph Stalin's unilateral boundary demarcations and ethnic population resettlement programs respectively influencing these contemporary conflicts. As a historical, contested instance of mass violence, the 1932-1933

\footnotetext{
1 Scott Straus, "Destroy Them to Save Us:' Theories of Genocide and the Logics of Political Violence," Terrorism and Political Violence 24, no. 4 (2012), 551-555; Ernesto Verdeja, "The Political Science of Genocide: Outlines of an Emerging Research Agenda," Perspectives on Politics 10, no. 2 (2012), 311-313.

2 Verdeja, Political Science, 308.

${ }^{3}$ The following exemplifies this trend and its value. See Matthew Krain, "State-Sponsored Mass Murder: The Onset and Severity of Genocides and Politicides," The Journal of Conflict Resolution 41, no. 3 (1997), 331-360; Barbara Harff, "No Lessons Learned from the Holocaust? Assessing Risks of Genocide and Political Mass Murder since 1955," American Political Science Review 97, no. 1 (2003), 57-73; Benjamin Valentino, Final Solutions: Mass Killing and Genocide in the 20th Century (Ithaca: Cornell University Press, 2004); Alex Bellamy, "Mass Atrocities and Armed Conflict: Links, Distinctions, and Implications for the Responsibility to Protect," The Stanley Foundation Policy Brief, February 2011, accessed September 1, 2019, 1-4, https://stanleycenter.org/publications/pab/ BellamyPAB22011.pdf.

4 Scott Straus, "Second-Generation Comparative Research on Genocide," World Politics 59, no. 3 (2007), 476-478; Verdeja, Political Science, 307-308.

${ }^{5}$ Straus, Destroy Them, 552-553.
}

Kristina Hook. "Pinpointing Patterns of Violence: A Comparative Genocide Studies Approach to Violence Escalation in the Ukrainian Holodomor." Genocide Studies and Prevention 15, no. 2, 10-36. https://doi.org/ 10.5038/1911-9933.15.2.1809.

(c) 2021 Genocide Studies and Prevention. 
Holodomor-an artificially induced famine in Stalin's Soviet Ukraine ${ }^{6}$ which killed an estimated 3.9 to 5 million people ${ }^{7}$-is ripe for its extensive documentation to be analyzed from a comparative genocide framework. The Holodomor is one of the more widely explored examples of Soviet famines within Eastern European studies (with some emerging social science scholarship). ${ }^{8}$ Legal scholars have utilized this case study to question genocidal statutes of limitations ${ }^{9}$ and the overlap of actus reus (the action which constituted the crime) and mens rea (the knowledge or intent of wrongdoing). ${ }^{10}$ Still, the Holodomor case has thus far had a less significant impact on broader comparative genocide theorizing of how mass violence unfolds or can be prevented. I focus on this research gap, using the Holodomor to demonstrate that chaotic patterns of violence can be empirically organized with the most important dynamics for prevention policy decision-making amplified. Drawing on all available archival sources, I code the 1932-1933 correspondences directly to and from Soviet leader Joseph Stalin regarding Ukraine to display how decision-making shifted in the two areas of intended targets and purpose. The ability of this framework to detect change over time and the correlation of the two key violence characteristics originally suggested by Straus ${ }^{11}$ is significant, indicating these approaches can be applied to empirically organize patterns in other mass killings. As my work demonstrates the emergence of genocidal criteria in the Holodomor, my framework ultimately concurs with other scholars who have labeled the Holodomor a genocide. ${ }^{12}$

${ }^{6}$ Many historians include the Kuban region, which although held by the Russian republic's Northern Caucasus province, was mainly populated by Ukrainians.

7 Significant demographic analyses on Holodomor deaths include the following works. See Oleh Wolowyna et al., "Monthly Distribution of 1933 Famine Losses in Soviet Ukraine and the Russia Soviet Republic at the Regional Level." Nationalities Paper 48, no. 3 (2020), 530-548; Nataliia Levchuk et al., "Regional 1932-1933 Famine Losses: A Comparative Analysis of Ukraine and Russia," Nationalities Papers 48, no. 3 (2020), 492, 510; Harvard Ukrainian Research Institute (HURI), "The Great Famine Project," MAPA: Digital Atlas of Ukraine, 2018, accessed January 1, 2020, http://gis.huri.harvard.edu/historical-atlas/the-great-famine.html; Omelian Rudnytskyi et al., "Demography of a Man-Made Human Catastrophe: The Case of Massive Famine in Ukraine 1932-1933," Canadian Studies in Population 42, no. 1-2 (2015), 53; Oleh Wolowyna, "Demographic Dimensions of the 1932-33 Famine in Ukraine," in Famine in Ukraine, 1932-1933: Genocide by Other Means, eds. Taras Hunczak and Roman Serbyn (New York: Shevchenko Scientific Society, 2007), 98-114; Oleh Wolowyna, "Comments on the Demographic Consequences of the Holodomor," Harvard Ukrainian Studies 30, no. 1-4 (2008), 243-IX; Jacques Vallin et al., "The Great Famine: Population Losses in Ukraine," in Holodomor Reflections on the Great Famine of 1932-1933 in Soviet Ukraine, ed. Lubomyr Y. Luciuk and Lisa Grekul (Kingston: Kashtan Press, 2008), 35-46; Norman M. Naimark, Stalin's Genocides (Princeton: Princeton University Press, 2010), 70-79; Anne Applebaum, Red Famine: Stalin's War on Ukraine (New York: Knopf Doubleday Publishing Group, 2017).

8 Arturas Rozenas and Yuri M. Zhukov, "Mass Repression and Political Loyalty: Evidence from Stalin's 'Terror by Hunger,'” American Political Science Review 113, no. 2 (2019), 569-583.

${ }_{9}^{9}$ Myroslava Antonovych, "Legal Accountability for the Holodomor-Genocide of 1932-1933 (Great Famine) in Ukraine," Kyiv-Mohyla Law and Politics Journal 1, no. 1 (2015), 159.

10 Andriy Semotiuk, “The Ukrainian Holodomor-Was It a Genocide?," Famine-Genocide in Ukraine (2008), 1-7, accessed September 1, 2019, https:/ / myworkvisa.com/usa/downloads/Holodomor.pdf.

${ }^{11}$ Straus, Destroy Them, 552-553.

12 For scholarly works labeling the Holodomor a genocide, see Andrea Graziosi, "The Soviet 1931-1933 Famines and the Ukrainian Holodomor: Is a New Interpretation Possible, and What Would the Consequences Be?," Harvard Ukrainian Studies 27, no. 1 (2004), 106-109; Nicolas Werth, "The Great Ukrainian Famine of 1932-1933," Mass Violence and Resistance, 2008, accessed August 20, 2019, https://www.sciencespo.fr/mass-violence-war-massacreresistance/en/document/great-ukrainian-famine-1932-33; Nicolas Werth, "The Crimes of the Stalin Regime: Outline for an Inventory and Classification," in The Historiography of Genocide, ed. Dan Stone (New York: Palgrave, 2008), 406-408, 414-415; Naimark, Stalin's Genocides, 15-29, 70-79; Bohdan Klid and Alexander J. Motyl, eds. The Holodomor Reader: A Sourcebook on the Famine of 1932-1933 in Ukraine (Toronto: Canadian Institute of Ukrainian Studies Press, 2012), xlii-xliv; George O. Liber, Total Wars and the Making of Ukraine, 1914-1954 (Toronto: University of Toronto Press, 2016), 192-197. Of historical interest, Raphaël Lemkin labeled the Ukrainian case a genocide in a 1953 essay, calling it "perhaps the classic example of Soviet genocide, its longest and broadest experiment in Russification, the destruction of the Ukrainian nation," quoted in Roman Serbyn, "Lemkin on Genocide of Nations," Journal of International Criminal Justice 7, no. 1 (2009), 126. 


\section{Historical Context of the Holodomor and Scope of Research}

Striking for its devastatingly short time span, the Holodomor ("killing by hunger") resulted in every eighth person in Ukraine perishing from 1932 to $1934 .{ }^{13}$ These events took place within the larger context of persistent Soviet famines, including the 1932-1933 all-Union famines that killed millions across the grain-producing areas of the North Caucasus, Volga region, Kazakhstan, Western Siberia, and the South Urals. ${ }^{14}$ Despite many debated aspects, commonly suggested contributing factors to the all-Union famines include the forced, often-violent collectivization accompanying the 1928 implementation of Stalin's first five-year plan aimed at industrial revitalization (replacing Vladimir Lenin's New Economic Policy of the early 1920s), grain requisitions, over-rapid economic transformation, agricultural workforce issues (e.g., decreasing laborers, forced transition of Kazakh herding practices), 15 and weather conditions. Foundational food security research states the "inescapable" conclusion that modern famines, "despite the role of [contributing] natural causes...are man-made," as they are primarily driven by issues of food access. ${ }^{16}$ This subject's more profound debates therefore question not whether the Holodomor and other Soviet famines were artificially induced, but 1) the degree of willful violence, as opposed to deadly incompetence, and 2) the presence of group-specific targeting.

Focusing this analysis on Stalin's intentionality in the Ukrainian case, I note Liber's data demonstrating a 1930 tenfold increase in collectivization-driven peasant rebellions across the Soviet Union, with 30 percent occurring in the Ukrainian Soviet Socialist Republic (SSR). ${ }^{17}$ Ukrainian lands experienced a deadly combination of grain requisitions; unworkable grain quotas; denial of requested food aid; seizure and destruction of food, seeds (the foundation of the following year's harvest), and agricultural equipment; infamous black boards where villages were sealed to prevent hunger-driven out-migration; and the capture of fleeing peasants from train stations by soldiers who pursued and returned them to their desolated villages. 18 Some of these dynamics were also present in other Soviet famines. However, Kulchytsky ${ }^{19}$ argues that while the Holodomor was linked to broader Soviet socioeconomic policies, it constituted a unique genocidal variant within the Stalinist regime's broader lethal policies. ${ }^{20}$ Despite all-Union attempts by Lenin and Stalin to "Sovietize"-i.e., transform economic and sociocultural identities-the countryside, Kulchytsky highlights four overlapping dynamics as demonstrating Ukrainian-specific targeting: physical blockades, seizure of all food, selective aid, and informational censure. These injurious directives coincided with Stalin's termination of existing Ukrainization policies, while also attacking Ukrainian party units. ${ }^{21}$

13 Serhii Plokhy, The Gates of Europe: A History of Ukraine (New York: Basic Books, 2015), 253.

14 For a variety of interpretations, see R.W. Davies and Stephen G. Wheatcroft, The Years of Hunger: Soviet Agriculture, 1931-1933 (New York: Palgrave Macmillan, 2004); Michael Ellman, "Stalin and the Soviet Famine of 1932-1933 Revisited," Europe-Asia Studies 59, no. 4 (2007), 663-693; Hiroaki Kuromiya, “The Soviet Famine of 1932-1933 Reconsidered," Europe-Asia Studies 60, no. 4 (2008), 663-675.

15 For Kazakhstan famine details, see Sarah Cameron, The Hungry Steppe: Famine, Violence, and the Making of Soviet Kazakhstan (Ithaca: Cornell University Press, 2018).

16 Nevin S. Scrimshaw, "The Phenomenon of Famine," Annual Review of Nutrition 71, no. 1 (1987), 1. For an analysis of the political causes of famine, see Stephen Devereux, "Introduction: From 'Old Famines' to 'New Famines'" in The New Famines: Why Famines Persist in an Era of Globalization, eds. Stephen Devereux (New York: Routledge, 2007), 126. For another seminal work in famine studies, see Amartya Sen, Poverty and Famines: An Essay on Entitlement and Deprivation (Oxford: Oxford University Press, 1981).

17 Liber, Total Wars, 147.

18 Klid and Motyl, Holodomor Reader, 175-305; Werth, Great Ukrainian Famine; Graziosi, Soviet Famines, 97-115; Applebaum, Red Famine, 186-277.

19 In the 1980s, Stanislav Kulchytsky was one of the first Ukrainian historians to study the Holodomor, first describing it as an unintentional outcome of collectivization but evolving considerably in his views after 1991.

20 Stanislav Kulchytsky, The Famine of 1932-1933 in Ukraine: An Anatomy of the Holodomor, trans. Ali Kinsella (Toronto: Canadian Institute of Ukrainian Studies Press, 2018), 49-128.

21 Plokhy, Gates of Europe, 254. 
Multiple scholars have argued that Soviet authorities could have saved between 5 million ${ }^{22}$ to 7.8 million $^{23}$ lives by diverting huge quantities of grain exports to famine-impacted territories, with Medvedev concluding "only half of the grain that was exported in 1932-1933 would have been sufficient to save all the southern regions from famine." 24 As Ukrainian lands-especially in the eastern, southern, and central regions of Ukraine's modern boundaries-were depopulated due to the fatalities, Soviet records show organized campaigns to repopulate these lands with ethnic Russians and other Soviet citizens by late 1933.25 Going beyond the Soviet Union's documented history of deportations and population resettlements, ethnic Russians also filled Soviet Ukraine's institutions to bolster the Ukrainian Communistic Party: by January of 1934, only four out of twelve members of the Ukrainian Communist Party Politburo were Ukrainians. ${ }^{26}$ In addition to social engineering and political institution takeover, the Holodomor resulted in a physically weakened, deeply traumatized populace, "crushing its capacity for open resistance to the regime for generations to come." 27 Using hunger as a weapon of violence, Stalin managed to transform a Ukrainian national movement that declared an independent statehood from 1917 to 1921 into an "exemplary Soviet republic" as he wrote in a letter to a close associate. ${ }^{28}$

Harsh repressions and informational blockades have contributed to Holodomor controversies today. References to "food difficulties" only appeared in Soviet scholarship in 1956, with the word "famine" itself not appearing until 1987. ${ }^{29}$ When considering other works that have addressed the question of genocide in the 1932-1933 Holodomor, I carefully weighed dissenting views. Some historiographies view 1932-1933 as an artificial separation from broader chronological dynamics or other Ukrainian famines in the 1920s, late 1930s, or post-World War II. Another debate probes whether governmental grain seizures can accurately be interpreted as a form of annihilating violence, a question hanging over other Soviet famines as well. Here, Rosenberg and Silina provide a relevant counterpoint in their detailed analysis of why starvation, with its slow and dehumanizing destruction, deserves special recognition within legal definitions of genocidal violence. ${ }^{30}$ Furthermore, Davies and Wheatcroft have blamed the Ukrainian famine on gross bureaucratic incompetence, saying, "the story which has emerged is of a Soviet leadership which was struggling with a famine crisis which had been caused partly by their wrongheaded policies, but was unexpected and undesirable." ${ }^{31}$ Contestations as to whether grain requisitions constitute willful violence evoke debates involving the methods of mass deaths in other contested genocide cases including various Native American experiences. ${ }^{32}$ I concur with other scholarship stressing the intention of the violence over the various methods by which it can be achieved. ${ }^{33}$ In describing conceptual challenges regarding intentionality, Verdeja suggests "emergent intentionality" and "cascading radicalization" as

\footnotetext{
22 Ellman, Stalin and the Soviet Famine, 679.

${ }^{23}$ Kuromiya, Soviet Famine, 665.

24 Roy A. Medvedev, Let History Judge: The Origins and Consequences of Stalinism (New York: Columbia University Press, 1989), 243

${ }^{25}$ Klid and Motyl, Holodomor Reader, 262.

${ }_{26}$ Applebaum, Red Famine, 291.

27 Plokhy, Gates of Europe, 254.

28 Ibid.

29 Andrea Graziosi et al., "Introduction to After the Holodomor: The Enduring Impact of the Great Famine on Ukraine," Harvard Ukrainian Studies 30, no. 1 (2008), xv.

30 Sheri Rosenberg and Everita Silina, "Genocide by Attrition: Slow and Efficient," in Genocide Matters: Ongoing Issues and Emerging Perspectives, eds. Joyce Apsel and Ernesto Verdeja (New York: Routledge, 2013), 106-126.

31 Davies and Wheatcroft, Years of Hunger, 441.

32 For a summary of these debates, see Benjamin Madley, "Reexamining the American Genocide Debate: Meaning, Historiography, and New Methods," American Historical Review 120, no. 1 (2015), 98-139.

33 Verdeja, Political Science, 309-312; Straus, Destroy Them, 550-552.
} 
more productive. ${ }^{34} \mathrm{He}$ notes that assumptions of prior explicit intentionality prove problematic for many well-accepted cases like the Holocaust, Armenia, and Rwanda35-a point applicable to debates over whether Stalin caused or capitalized on existing hunger to achieve more pronounced destruction. Taking a similar approach, Kulchytsky has stressed genocidal intentionality in the Holodomor but dated its roots and the wider all-Union famine to 1927, prior to the Great Break economic changes in 1928-1929.36 With unequivocal confessions of genocidal guilt lacking in nearly every suggested case, I also drew from Verdeja's methodological suggestion ${ }^{37}$ to overlay the perpetrators' capacity to inflict violence with their behavior (level of lethality, degree of coordination, and scope) in designing the proxy variables presented later in this article. Proxy variables are of particular importance when studying ultimate decision-makers, for as Kulchytsky reminds, Stalin was not obligated in any records to record why he had instituted the Holodomor. ${ }^{38}$ Thus, similar to Davies and Wheatcroft, ${ }^{39}$ I also find the question of genocide intentionality to be central but elected to address this question empirically through proxy variables, with my research findings diverging from their explanation of incompetence. 40

Other alternative Holodomor interpretations question whether an ethnonational element was present in the targeting of Ukrainians, especially in light of other famines and violence throughout the Soviet Union. ${ }^{41}$ Some scholars counter that the 1932-1933 Holodomor presents sufficient evidence of willful ethnonational targeting not present in other Ukrainian famines or in the additional all-Union famines. ${ }^{42}$ In this article, I make no claims regarding other Ukrainian famines. As I avoid ethnic targeting explanations for the violence, I also do not argue that the Holodomor should be considered a genocide at the expense of other Soviet famines or violence. This article's methodology could easily be applied to other cases; this would expand upon-rather than negate-the patterns my analysis uncovered. Regarding the position that Stalin willfully targeted ethnic Ukrainians, this argument is often undertaken by those exploring whether the Holodomor adheres to the 1948 United Nations definition of genocide. 43 The definition's notable exclusion of groups like political and economic groups has long been critiqued $^{44}$ but elevates the importance of ethnic motivations for those seeking international genocide recognition for the Holodomor. This article is not intended to re-address the compatibility of the Holodomor with the United Nation's definition, as this debate has been

\footnotetext{
${ }^{34}$ Verdeja, Political Science, 310.

35 Ibid.

36 Kulchytsky, Famine 1932-1933, xx, 29.

37 Verdeja, Political Science, 310.

38 Stanislav Kulchytsky, "Why Did Stalin Exterminate the Ukrainians? Comprehending the Holodomor: The Position of Soviet Historians, Part 4," The Day Weekly Digest no. 37, November 22, 2005, accessed December 1, 2019, https:// www.usubc.org/AUR/aur621.php\#a4.

${ }^{39}$ Davies and Wheatcroft, Years of Hunger, 441.

${ }^{40}$ While an extended summary of this debate is beyond this article's scope, I note other dissenting voices who generally concur with Davis and Wheatcroft's explanation of Soviet incompetence in famine deaths. See Terry Martin, Affirmative Action Empire: Nations and Nationalism in the Soviet Union, 1923-1939 (Ithaca: Cornell University Press, 2001); Sheila Fitzpatrick, Stalin's Peasants: Resistance and Survival in the Russian Village after Collectivization (New York: Oxford University Press, 1994). For another summary of genocide debates within Soviet historical circles, see Norman M. Naimark, "Applebaum, Fitzpatrick, and the Genocide Question," Contemporary European History 27, no. 3 (2018), 435-439.

41 Viktor Kondrashin, "Hunger in 1932-1933: A Tragedy of the Peoples of the USSR," Holodomor Studies 1, no. 2 (2009), 16-21, accessed September 27, 2020, https://holodomor.ca/wp-content/uploads/2016/09/2.-HolodomorScholarship-MY.pdf.

${ }^{42}$ Klid and Motyl, Holodomor Reader, xxviv-xlv.

${ }^{43}$ United Nations, General Assembly Resolution 260, Convention on the Prevention and Punishment of the Crime of Genocide, December 9, 1948 (UN Doc. A/RES/260(III)).

${ }^{44}$ Verdeja, Political Science, 309.
} 
recently (though not exhaustively) covered by Applebaum, ${ }^{45}$ nor is it directly intended to support or detract from other Holodomor-related political activities like commemorations, legal judgements, or modern-day consequences like reparations. Instead, the purpose of this article is to operationalize existing comparative genocide scholarship in the context of the Holodomor case, with a focus on understanding how this historical case may help violence prevention experts to rapidly make sense of complex patterns of violence in real-time. Scholarly questions remain as to whether the "rather arbitrary distinction between victim categories" 46 suggests politicization and / or an inherent empirical flaw in the United Nations definition; I follow other scholarly approaches that encourage empirically-based innovation regarding group characterization. ${ }^{47}$

In dealing with the complex question of Holodomor-era Ukrainian identity, several considerations guided my approach. Liber utilizes "majority Ukrainian-speaking territories" 48 terminology in his study, clarifying that "this does not presuppose a developed national consciousness...nor does it imply an 'ethnically pure' Ukrainian population." 49 Stating that peasant identity was likely stronger than Ukrainian identity-with the exception of urban Ukrainophile movement representatives ${ }^{50}$ - he argues that social position and religious adherence were key factors in defining one's self-identification. ${ }^{51}$ A 1926 census found 90 percent of the rural population self-identifying as Ukrainian, with 81 percent of Ukraine's 29 million residing in rural areas, ${ }^{52}$ a factor that helps to explain the extensive cultural heritage destruction of the Holodomor ${ }^{53}$ even without subscribing to purely ethnic Ukrainian motivations. During this period, Ukrainian self-identification was further complicated by debates over relationships between smaller sub-ethnicities, ever-present language distinctions, and Ukrainian spread over various political empires.

While contextually helpful, genocide scholarship has long-focused the question of group membership as "defined by the perpetrator." 54 Under Lenin's New Economic Policy, a divide-and-conquer strategy separated rural laborers into three economic classes (kulaks, seredniaks, and bedniaks), a tactic Kulchytsky argues was intended to encourage strife, reduce unified resistance, and discourage collective identity development. 55 The broader debates of Lenin and Stalin's views on nationality policy are beyond the scope of this article, but a prevailing interpretation of Lenin's pragmatist approach has included the pacification of Ukrainian peasantry by allowing state participation. 56 When Stalin consolidated power, "a mode of hybrid Soviet identity crystalized, rooted in both nationality and perceived class

\footnotetext{
${ }^{45}$ Applebaum, Red Famine, 346-360.

${ }^{46}$ Verdeja, Political Science, 309.

47 For examples of this approach, see Straus, Destroy Them, 552-555; Mark Osiel, Making Sense of Mass Atrocity (Cambridge: Cambridge University Press, 2009); Larry May, Genocide: A Normative Account (Cambridge: Cambridge University Press, 2010).

48 Liber, Total Wars, xvi.

${ }^{49}$ Ibid.

50 Plokhy, Gates of Europe, 159-188.

${ }^{51}$ Liber, Total Wars, 12-28.

52 Ibid., 145 .

53 Olga Andriewsky, "Towards a Decentered History: The Study of the Holodomor and Ukrainian Historiography," in Contextualizing the Holodomor: The Impact of Thirty Years of Ukrainian Famine Studies, eds. Andrij Makuch and Frank Sysyn (Toronto: Canadian Institute of Ukrainian Studies Press, 2015), 39-40; Kristina Hook, "When the Ukrainian World Was Destroyed:' Genocidal Narrative Convergence and Stakeholder Interactions during National Crises," (PhD diss., University of Notre Dame, 2020), 44-87, https:// curate.nd.edu/show/jw827943j9c.

${ }^{54}$ Frank Chalk and Kurt Jonassohn, The History and Sociology of Genocide: Analyses and Case Studies (New Haven: Yale University Press, 1990), 35.

${ }^{55}$ Kulchytsky, Famine 1932-1933, 26-30.

56 Ibid., 26-30; Graziosi, Soviet Famines, 100. See also, Francine Hirsch, Empire of Nations: Ethnographic Knowledge and the Making of the Soviet Union (Ithaca: Cornell University Press, 2005); Martin, Affirmative Action Empire.
} 
origins...Ukrainian nationality and agricultural identity-kulak, seredniak, or bedniak."57 Along this interpretation, Stalin's efforts to supersede the NEP involved taking on the dual, intertwined threats that Ukrainian lands posed: economic and national. Peasant resistance shifted rural self-perceptions; the lines between the wealthier kulaks and lower economic classes blurred as a more cohesive resistance was achieved. Graziosi summarizes an indivisible linkage between class and nationality in crystalizing the perpetrator-defined category of Holodomor-era Ukrainian by stating, "at least up to 1933, the national question was the peasant question." 58 With Stalin's push to actualize socialism across all fronts, it is reasonable to inferas I do in the proxy variables presented later-that perpetrator perceptions of "Ukrainian" developed into the economic-national category of those strongly resisting their recasting as beneficial Soviet citizens and likely included a variety of minority groups residing in Ukrainian lands.59 Such a point is especially helpful to emphasize here, as the perpetrator-driven Ukrainian/Soviet distinction exists separately to Ukrainian ethnic membership and does not correlate precisely to Ukrainian/non-Ukrainian surnames in the surveyed documents.

\section{Overcoming the Challenges of Defining and Assessing Genocides}

Debates over the Nature and Measurement of Genocides

As referenced, the Holodomor is important for scholars operating across academic fields ${ }^{60}$ and for those seeking legal and/or political redress for long-suppressed crimes, a dynamic related to genocide's powerful symbolic capital. The shocking brutality of the Nazi regime against more than six million Jews and other populations influenced its special moral authority, even in comparison to other acts of barbarity like war crimes or crimes against humanity. The dark side of technological and industrial advancements-which facilitated the Nazis' horrific killing efficiency-shattered optimism, ${ }^{61}$ while burgeoning mass media spread visual proofs of the Holocaust into ordinary homes and shaped popular understandings of genocide. ${ }^{62}$ The subject of genocide today remains a highly contested yet morally powerful category used by a range of professionals (e.g., advocacy activists, policymakers, journalists, politicians, lawyers, etc.). Especially important for contested, long-suppressed cases like the Holodomor, clarifying that multiple actors employ varying working definitions for a variety of purposes-ranging from the political, legal, remembrance, and academic — must be stated upfront.

${ }^{57}$ Amber N. Nickell, "Book Review: The Famine of 1932-1933 in Ukraine: An Anatomy of the Holodomor, by Stanislav Kulchytsky," Canadian Slavonic Papers 61, no. 4 (2019), 458.

58 Graziosi, Soviet Famines, 100. See also, Hennadii Yefimenko, “The Kremlin's Nationality Policy in Ukraine after the Holodomor of 1932-1933," Harvard Ukrainian Studies 30, no. 1 (2008), 69-70.

59 Ibid.

${ }^{60}$ For the purpose of this analysis, I draw a distinction between debates over the Ukrainian genocide question in two important academic fields: those occurring within Soviet Union historical studies and those within comparative genocide theorizing. The former often champions a more traditional historical analysis of archival records, prioritizing deep interpretation of documents in their chronological context of Ukraine, the region, and the Soviet Union. Alternatively, comparative genocide theorizing has developed into an interdisciplinary academic field that focuses on conceptual innovations derived from comparing large-scale violence in global perspective (e.g., eliciting shared violence patterns, precipitating factors, psychological similarities, etc.), often applying analytic methods to inform the prevention of future genocides. Although not exhaustive, a representative selection of the latter's voices includes Maureen Hiebert, Joyce Apsel, Scott Straus, Adam Jones, Ernesto Verdeja, Benjamin Valentino, Daniel Chirot and Clark McCauley, among others. While Soviet Union historical studies and comparative genocide theorizing can overlap and inform each other, epistemological variations sometimes result in legitimate differences of analysis, interpretation, and emphasis. Grounded in comparative genocide theorizing, my work is primarily intended to contribute to this field's conceptual and methodological conversations regarding how to trace mass violence patterns in the Ukrainian case and in other global contexts, past and present. Both essential to the knowledge production process, I recognize the value of Soviet Union historical studies and comparative genocide theorizing, while situating my analysis within the latter.

61 Zygmunt Bauman, Modernity and the Holocaust (Cambridge: Polity Press, 1989), 1-30.

62 For additional details, see Akiba Cohen et al., The Holocaust and the Press: Nazi War Crime Trials in Germany and Israel (Cresskill: Hampton, 2002). 
Good faith academic disagreements over the scope and parameter of the genocide concept have existed since genocide studies took a comparative turn in the 1970s. ${ }^{63}$ Without negating the significant role of founding voices, including Raphaël Lemkin ${ }^{44}$ and Hannah Arendt, ${ }^{65}$ some scholars have noted the powerful political processes that exerted pressure on the specific international law formulation of genocide terminology. ${ }^{66}$ Others urged that the inclusion of additional cases, particularly from non-Western perspectives, should prompt an analytic reexamination of the assumptions guiding genocide research. ${ }^{67}$ Adapting increasingly sophisticated methodologies, alternative analytic conceptualizations, and associated variables fostered significant theoretical breakthroughs. These developments also expanded the conceptual boundaries of genocide, with Jones gathering 25 distinctive definitions proposed by well-known scholars. ${ }^{68}$ Legal scholars raise valid concerns about the importance of precedent and analytical consistency. However, Jones argues persuasively that scholarly conceptual debates are essentially consistent with internal law debates over "hard" and "soft" legal applications. ${ }^{69}$ Some scholars have argued that the original United Nations definition is too rigid, thus ruling out many horrific acts that deserve the special international condemnation of genocide terminology. Dissenters respond that over-applied references to genocide will rob it of its moral weight and undercut preventative efforts by resulting in non-tailored responses to all forms of mass violence.

A universally accepted definition of genocide is elusive, complicating comparability across case studies. After reviewing seven major genocide comparative volumes, Straus stated that "no two authors under review share the same definition of the term [genocide], and as a result the authors end up explaining fairly different phenomena." 70 Essential for genocide prevention policymaking, I note one key methodological divide, referring for clarity to this distinction as numerical thresholds or dynamics-based classifications. Regarding the former, social sciences like political science and psychology have increasingly emphasized the research potential of quantitative modeling to explain social and behavioral dynamics including war, violence, and peacebuilding. ${ }^{71}$ Some of these scholars have turned their attention to mass murder and have opted to circumnavigate genocide definition debates by instead comparing various instances of high-fatality violence. ${ }^{72}$ Recognizing that the numerical categories they propose may not fully align with traditional understandings of genocide, new conceptual categories, like "politicide" or "political mass murder"73 have replaced strictly genocide-focused analyses. In addition, the actual number of victim fatalities constitutes a large range, ranging

${ }^{63}$ Adam Jones, Genocide: A Comprehensive Introduction, 3rd ed. (New York: Routledge, 2017), 11-27; Verdeja, Political Science, 311-313.

64 Raphaël Lemkin, Axis Rule in Occupied Europe: Laws of Occupation, Analysis of Government, Proposals for Redress (Washington, DC: Carnegie Endowment for International Peace, Division of International Law, 1944).

${ }^{65}$ Hannah Arendt, The Origins of Totalitarianism (New York: Harcourt Brace Jovanovich, Inc., [1956] 1973).

${ }^{66}$ Naimark, Stalin's Genocides, 80-98; Douglas Irvin-Erickson, Raphael Lemkin and the Concept of Genocide (Philadelphia: University of Pennsylvania, 2017) 152-196.

67 Alexander Laban Hinton, "Critical Genocide Studies," in Genocide Matters: Ongoing Issues and Emerging Perspectives, eds. Joyce Apsel and Ernesto Verdeja (London: Routledge, 2013), 46, 54-55.

68 Jones, Genocide, 23-24.

${ }^{69}$ Ibid., 28; see also, Christopher Rudolph, "Constructing an Atrocities Regime: The Politics of War Crimes Tribunals," International Organization 55, no. 3 (2001), 655-691.

${ }^{70}$ Straus, Second Generation, 478-479.

${ }_{11}$ Patrick M. Regan, "Quantitative Approaches," in Routledge Handbook on Peacebuilding, ed. Roger MacGinty (London: Routledge, 2013), 183-194; Department of Peace and Conflict Research, "Uppsala Conflict Data Program," Uppsala University, Sweden, 2017, accessed August 30, 2019, http://ucdp.uu.se/.

72 For a summary of these efforts, see Ernesto Verdeja "Predicting Genocide and Mass Atrocities," Genocide Studies and Prevention: An International Journal 9, no. 3 (2016), 13-28.

${ }^{73}$ Harff, No Lessons Learned, 58-59; Krain, State-Sponsored Mass Murder, 331-338. 
from Bellamy's 5,000 civilian death threshold for "mass atrocities"74 to Valentino's "mass killings," which he defines as 50,000 or more noncombatants deaths within five years. ${ }^{75}$ Other implicit references to genocide as related to numerical criteria have occurred in popular historical accounts, such as Hochschild's usage of the phrase "genocidal proportions" in reference to colonial Belgian Congo. ${ }^{76}$

Numerical approaches can play an important role in global horizon scanning 77 -where a wide rather than deep approach on mapping changes is needed-and provide important insight on some features of violence escalation. ${ }^{78}$ However, dissenters note that foundational understandings of genocide stress the perpetrators' intentional efforts to annihilate entire groups, with victim totals unspecified. Accordingly, as victims are selected due to their group membership, specific patterns across diverse cultural or chronological contexts should separate genocide as a complex phenomenon, even compared to other severe violence. ${ }^{79}$ Genocide's unique dynamics may occur with high or low body counts; fatalities can include "only a few hundred...if the targeted population is small and localized, or millions if it is large and widespread." 80 Other scholars support this view indirectly by arguing that genocides should be re-contextualized within broader social science literature without losing sight of what makes this phenomenon unique, ${ }^{81}$ necessitating that distinctive dynamics both exist and can be traced.

\section{Now-Casting and the Need for a Dynamics-Based Approach}

I suggest the dynamics-based approach is best situated to meet recognized gaps within genocide prevention research. In addition to early warning tools (which flag imminent threats of genocide or other mass violence) and risk assessments (which track gradually emerging accumulations of structural risks), a new push focuses on now-casting tools aimed at distilling the chaos of mass violence while amplifying the most significant dynamics for policymaking as they change in real-time. ${ }^{82}$ For this third type of tool, a framework built for dynamics-based classifications of mass killings is urgently needed. Taken alone, numerical counts of victims can undercut such research goals by obscuring contextual nuance and emerging patterns, conflating related-but-distinct forms of large-scale violence if they share similar fatality rates. While morally deplorable, high fatality rates do not automatically indicate that an entire population group was targeted for the extermination of genocide. Instead, dynamics-based now-casting elicits more nuanced questions regarding victim selection, perpetrator motivation, cascading violence scenarios, tipping points, and potentially successful violence interventions, ${ }^{83}$ while allowing for the incorporation of cross-cultural factors that can profoundly shape the design, monitoring, and ultimate success of an intervention. Numerical approaches capture some aspects of change (e.g., variation in the number of fatalities across time and space). Yet they

\footnotetext{
74 Bellamy, Mass Atrocities, 2.

75 Valentino, Final Solutions, 11-12.

${ }^{76}$ Adam Hochschild, King Leopold's Ghost: A Story of Greed, Terror, and Heroism in Colonial Africa (New York: Houghton Mifflin Company, 1998), 225.

77 Kristina Hook, “Forecasting Policy Trends," Anthropology News, July 13, 2018, accessed January 6, 2019, https:// doi.org/10.1111/AN.907.

78 Verdeja, Predicting Genocide, 13-32.

79 Straus, Destroy Them, 551-555; Hinton, Critical Genocide Studies, 46, 54-55.

80 Daniel Chirot and Clark McCauley, Why Not Kill Them All? The Logic and Prevention of Mass Political Murder (Princeton: Princeton University, 2006), 17.

81 Verdeja, Political Science, 311-313.

82 Birger Heldt, "Atrocity Crimes as a Disease: A Statistical Approach to Early Detection," in Preventing Mass Atrocities: Politics and Practices, eds. Barbara Harff and Ted Gurr (New York: Routledge, 2019), 53-59; Philip E. Tetlock, "Second Thoughts about Expert Political Judgement: Reply to the Symposium," Critical Review: A Journal of Politics and Society 22, no. 4 (2010), 470.

83 Verdeja, Political Science, 316.
} 
cannot alone tell us if such changes are genocidal (i.e., oriented toward intentional destruction) or repressive-yet-not-genocidal-factors holding significant ramifications for prevention efforts.

A dynamics-based now-casting approach requires engaging what separates genocide from other forms of violence. Straus suggests consensus has clustered around two key questions for answering this: 1) Who is targeted, and 2) for what purpose? ${ }^{84}$ Equally important, another research trend stresses that genocides should be viewed as a process that can ebb and flow through its occurrence (i.e., exhibiting violence not technically classified as genocidal at every stage). ${ }^{5}$ Based upon this research, the spectrum of large-scale killings can be organized by separating genocidal patterns from another non-genocidal-but-still-severe form, which I refer to as mass directed violence, ${ }^{86}$ along the criteria of intended target and intended purpose. With reference to intended targets, genocide is characterized by unqualified group selection, while mass directed violence is characterized by qualified (i.e., partial) group selection..$^{87}$ Therefore, in a context of genocidal violence, perpetrators target every member of the threatened group, making no distinctions by gender, age, or other features. In a mass directed violence context, violence is still targeted along group lines, but not every member is targeted; for example, combatants or perceived rivals from within a group may be singled out for violence. Additionally, genocide is waged for an intended purpose of destruction, while the intended purpose of mass directed violence falls short of this annihilating goal. The destructive violence of genocide implies that perpetrators cannot envision a future that entails co-existing with their victims. In contrast, the goal of mass directed violence can involve their victims alive but in a subservient, submissive role with violence thus including repression, intimidation, or harm. While genocides and mass directed violence do not constitute a moral hierarchy, distinguishing between their specific, distinctive specific patterns of violence is essential for policy-oriented academic research. Effective violence responses are tailored to nuanced ground dynamics and must locate ripe moments for various types of interventions. The Holodomor case aids in theory development by allowing historical hindsight to be juxtaposed to empirical findings, with my approach described below.

\section{Methods}

Research Questions and Data Considerations

As Soviet era archives opened for researchers, ${ }^{88}$ new possibilities for analyzing the longsuppressed Holodomor emerged. ${ }^{89}$ Many relevant archives in Ukraine opened to researchers in $2008^{90}$ with another round of Soviet-related declassification in 2015. ${ }^{11}$ Other related documents

\footnotetext{
${ }^{84}$ Straus, Destroy Them, 546-548.

${ }^{85}$ Maureen S. Hiebert, “Theorizing Destruction: Reflections on the State of Comparative Genocide Theory," Genocide Studies and Prevention: An International Journal 3, no. 3 (2008), 328-335; Maureen Hiebert, "Questioning Boundaries: What's Old and What's New in Comparative Genocide Theory," in Genocide Matters: Ongoing Issues and Emerging Perspectives, eds. Joyce Apsel and Ernesto Verdeja (New York: Routledge, 2013), 34-36.

86 "Directed" denoting targeted intentionality.

87 This distinction mitigates an analytical challenge posed by the UN definition regarding destruction "in whole or in part," a distinction so broad it undercuts preventive early warning efforts.

88 “On Access of the Archives of Repressive Bodies of the Communist Totalitarian Regime from 1917-1991," 2540 Verkhovna Rada of Ukraine § 316-VIII (2015), accessed October 2, 2021, https://old.uinp.gov.ua/laws/lawukraine-access-archives-repressive-agencies-totalitarian-communist-regime-1917-1991.

89 Werth, Crimes Stalin Regime, 406-08, 414-415; Yuri Shapoval and Marta D. Olynyk, "The Holodomor: A Prologue to Repressions and Terror in Soviet Ukraine," Harvard Ukrainian Studies 30, no. 1 (2008), 99-100; Myroslav Shkandrij and Olga Bertelsen, "The Soviet's Regime's National Operations in Ukraine, 1929-1934," Canadian Slavonic Papers 55, no. 3-4 (2013), 417-420; Ruslan Pyrih, Holodomor of 1932-1933 in Ukraine: Documents and Materials, trans. Stephen Bandera (Kyiv: Kyiv Mohyla Academy Publishing House, 2008), 1-63, accessed August 19, 2019, http:// history.org.ua/LiberUA/PyrihHolodUkr_2008/PyrihHolodUkr_2008.pdf.

90 Shapoval and Olynyk, Holodomor: A Prologue, 99-100.

${ }^{91}$ Verkhovna Rada, Access of the Archives.
} 
are believed to remain in closed Russian Federation archives, ${ }^{92}$ although relevant records have been published since Russian political independence. ${ }^{93}$ Additional written records such as personal diaries and narrative oral accounts by survivors have also been published, providing poignant victim viewpoints.94 These new documents have altered preexisting research limitations, have allowed earlier scholarship to be reconsidered, and-for some scholars-have resulted in a theoretical sea change in recent years.

These documents confirm that, like other examples of mass deaths in the former Yugoslavia, Armenia, the Holocaust, Rwanda, and elsewhere, the Ukrainian Holodomor was a complex sociopolitical phenomenon characterized by varying levels of participation, a degree of intentionality that continues to be contested (as will be discussed further), and multiple layers of decision-making across a constellation of bureaucratic structures and regional authorities. Also familiar to scholars of violence, questions of retaliation, the parameters of self-defense, limitations on the state's monopoly of force, and other debates add complexity to the conceptual boundaries of "victim" categories. Without denying this reality, I elected to focus this study on the primary records of Soviet leader Joseph Stalin who had consolidated his control over the Soviet Union by $1932 .{ }^{95}$ With Stalin the central node of political authority, I restricted my scope to all available correspondences directly to and from him during the period of 1932-1933 that directly pertained to Ukraine. Aiming to include all documentation he can reasonably be inferred as personally viewing, I added several additional directives that contain his personal signature or that resulted in his immediate responsive action, such as firing an official.

Both Ukraine and the Soviet Union experienced a series of famines for a variety of reasons from the 1920s through the aftermath of World War II. Like other mass violence events (e.g., Straus' contention that the Rwandan genocide is best analyzed from 1990-1994), ${ }^{96}$ scholars debate the Holodomor's chronological duration within this broader context. While some proponents of the genocide hypothesis in Ukraine argue that the 1920s famines or the later 1930s purges must be considered, the 1932-1933 period is the most frequently suggested common denominator across the widest range of literature. Questions of genocide are dependent on the overlap of the perpetrators' motives (intentionality) and means (the ability to carry out the violence they intend). ${ }^{97}$ This study could be expanded to include other years and questions (such as do we see rhetorical escalations in 1931-1932 but with fewer deaths?) without definitely addressing genocidal questions (e.g., it is possible that Stalin's means emerged before his motivation, or vice versa). Thus, with the majority of scholars suggesting that mass deaths peaked in 1932-1933 (indicating at least the possibility of genocidal means), the question of whether motives (intentionality) can also be detected in this pivotal period is central. Accordingly, I restricted my analysis to the seventeen authenticated documents that I located to/from Stalin on Ukraine, dating from February 10, 1932 to October 2, 1933. Sixteen records were originally located in Russian archives, specifically the Russian State Archive of Socio-Political History (RGASPI) and the Archive of the President of the Russian Federation

\footnotetext{
92 Iryna Matiash, "Archives in Russia on the Famine in Ukraine," Harriman Review 16, no. 2 (2008), 36-45, accessed August 19, 2019, https:// docplayer.net/48842438-The-harriman-review-the-holodomor-of-papers-from-the-75thanniversary-conference-on-the-ukrainian-famine-genocide.html.

93 These works were published in examples including the following edited volumes. A.N. Sakharov, "Sovershenno Sekretno:" Lubianka-Stalinu o Polozhenii v Strane: v Chetyrekh Tomakh ["Top Secret:" From Lubianka to Stalin on the State of the Country in 4 Volumes] (Moscow: Institut Rossiiskoi Istorii RAN, 2001); Reginald Manning et al., eds., Tragedia Sovietskoi Derevni: Kolektyvizatsia i Raskulachivanie: Dokumenty i Materialy v Pyati Tomakh [Tragedy of the Soviet Countryside: Collectivization and Dekulakization: Documents and Materials, Volume 5] (Moscow: Rosspen, 2001).

${ }^{94}$ Anna Malpas, "Between the Lines: Historians Put Stalin-Era Diaries Online," AFP, March 27 2017, accessed September 1, 2019, https:/ / sg.news.yahoo.com/ between-lines-historians-put-stalin-era-diaries-online-055626150.html.

${ }^{95}$ Naimark, Stalin's Genocide, 70-79.

96 Scott Straus, The Order of Genocide: Race, Power, and War in Rwanda (Ithaca: Cornell University Press, 2006), 175-200.

${ }^{97}$ In legal terms, i.e., mens rea and actus reus, see William Schabas, Unimaginable Atrocities: Justice, Politics, and Rights at the War Crimes Tribunals (Oxford: Oxford University Press, 2012); Semotiuk, Holodomor Genocide.
} 
(APRF), published in the first decade of Russian independence. One additional record was located in Ukraine's Central State Archive of the Supreme Authorities and Governance of Ukraine in Kyiv (TsDAVO Ukrayiny). This article relies upon my translations and the work of a research assistant (a native speaker of Russian and Ukrainian) trained in ethnographic translation and working under my supervision. However, other English translations of these and other documents have also been published. 98

These seventeen documents are not fully representative of the full range of decisionmaking, perpetration, or complexity. Beyond Stalin's decision-making, this methodology could be expanded to address a wider range of Soviet bureaucracies and regional authorities;99 shifting perpetrator/victim/bystander categories; 100 or the interplay of local responses to and participation in Soviet collectivization. ${ }^{101}$ Innovative computational tools could also adapt these proxy variables into algorithms for more extensive coding across a greater number of documents, such as records kept during this time period by external observers including foreign diplomats. 102 Despite these limitations, tightly centralized decision-making within the Soviet Union and a widespread degree of institutionalized fear among the less powerful make focusing on Stalin's intentionality a foundational step. Fear and dread may have influenced the tone taken even by Stalin's close associates when they wrote to him, necessitating a careful read of the documents selected within their broader context. Historians have noted tonal shifts in surviving victim private recollections from the 1920s to early 1930s as harsh repressions were legally codified for discussing the famine or other topics deemed subversive. ${ }^{103}$ Still, other scholars may adapt this methodology in creative ways to include these important local voices. Within Holodomor historical reconstructions, a perceived change in Stalin's decision-making toward Ukraine was frequently flagged in autumn of $1932^{104}$ (discussed later). With this example in mind, two primary questions drove the textual approach I employed:

1. Do the records surveyed support an analytic assessment of the Holodomor as a genocide or mass directed violence, based on the conceptual categories of intended target and intended purpose?

2. Does the framework capture change over time, including shifts or multiple shifts (back-and-forth) across the genocide and mass directed violence conceptual categories?

98 Klid and Motyl, Holodomor Reader, 220-306; Pyrih, Holodomor of 1932-1933, 1-63.

${ }_{99}$ For a classic Holocaust-focused example, see Raul Hilberg, The Destruction of the European Jews (New Haven: Yale University Press, 2003); for lower-level Soviet bureaucrat archives, see Valeriy Vasyliev et al., eds. Partiyno-radianske Kerionytstvo Ukraiinskoii SSR Pid, Chas Holodomoru 1932-1933: Vozhdi, Pratsionyky, Actyvisty, Zbirnyk Dokumentiv ta Materialiv [Soviet-Party Leadership of the Ukrainian SSR during the Holodomor of 1932-1933: Leaders, Employees, Activists, Collection of Documents and Materials] (Kyiv: Institute of Ukrainian History, 2013).

${ }^{100}$ For one such example, see Raul Hilberg, Perpetrators, Victims, Bystanders: The Jewish Catastrophe 1933--945 (New York: Harper Collins, 1992).

101 For one such example, see Lee Ann Fujii, Killing Neighbors: Webs of Violence in Rwanda (Ithaca: Cornell University Press, 2009).

102 For additional sources of foreign diplomat records, see, Marco Carynnyk, Lubomyr Y. Luciuk, and Bohdan S. Kordan, eds., The Foreign Office and the Famine: British Documents on Ukraine and the Great Famine of 1932-1933 (Vestal: Limestone Press, 1988); Athanasius D. McVay and Lubomyr Y. Luciuk, eds., The Holy See and the Holodomor: Documents from the Vatican Secret Archives on the Great Famine of 1932-1933 in Soviet Ukraine (Kingston: Kashtan Press, 2011).

103 Malpas, Between the Lines.

104 Martin, Affirmative Action Empire, 98-121; Klid and Motyl, Holodomor Reader, xxviv-xlv; Applebaum, Red Famine, 222240. 
Overview of Methods Approach

To conduct this analysis, I used MAXQDA mixed methods data software, which aids in the visualization, rapidity, and uniformity of qualitative data coding and analysis.105 With its research design flexibility, it has been successfully utilized in textual analysis containing multiple themes and tonal characteristics, including by researchers controlling for temporal variation. Various epistemological perspectives exist for qualitative data analysis, with intercoder reliability an important component. ${ }^{106}$ Although grounded analysis calls for inductive approaches, I used a deductive approach for specific testing, also informed by discourse analysis approaches aimed at capturing temporal variation in textual and spoken sources. I incorporated the same native speaker and my translations for standardization and confirmed translational consistency with native speakers for intercoder reliability. Over the course of this project, I conducted 2.5 years of ethnographic research in Ukraine (2016-2019). I completed extensive interviewing with diverse scholarly experts, accessed additional archival sources, and conducted site visits to impacted locations, which provided additional context. I employed a systematic approach to document identification to reduce bias in potential selectivity of records and coded the full range of available documents before organizing the themes and sub-themes in any way, thus reducing unconscious bias tendencies to fit the data to previously noted patterns. Finally, I developed proxy variables for the categories of intended purpose and intended targets, a standard practice for social scientific approaches to elusive categories like "intentionality,"107 proxy variables that I have also employed in other geographically diverse cases. As mentioned, Stalin's power consolidation and the period's ideological monopoly left other authority figures vulnerable to crossing his official, definitive interpretations of party loyalty. To address the challenges of assessing motives in such an environment, I drew from Verdeja's analytic suggestions and emergent intentionality 108 conception to overcome related methodological obstacles in other similar contexts.

Table 1. Proxy Variables, Intended Purpose of Violence

\begin{tabular}{|c|c|c|c|}
\hline & Intended Purpose & $\begin{array}{l}\text { Proxy Variable: Future- } \\
\text { Orientation }\end{array}$ & $\begin{array}{l}\text { Proxy Variable: Violence as } \\
\text { Communicative } \\
\text { [Violence used to send } \\
\text { messages of fear or } \\
\text { intimidation] }\end{array}$ \\
\hline GENOCIDE & - Destruction & $\begin{array}{l}\text { - Perpetrators cannot } \\
\text { envision a future that } \\
\text { entails co-existing with } \\
\text { victims. }\end{array}$ & $\begin{array}{l}\text { - Little to no communicative } \\
\text { violence }\end{array}$ \\
\hline $\begin{array}{l}\text { MASS } \\
\text { DIRECTED } \\
\text { VIOLENCE }\end{array}$ & $\begin{array}{l}\text { - All other violence } \\
\text { falling below } \\
\text { destruction } \\
\text { - Repression } \\
\text { - Non-destructive } \\
\text { harm (e.g., injuries) }\end{array}$ & $\begin{array}{l}\text { - Perpetrators can } \\
\text { envision a future that } \\
\text { includes their victims in } \\
\text { a submissive role. }\end{array}$ & $\begin{array}{l}\text { - Extensive evidence of } \\
\text { communicative violence }\end{array}$ \\
\hline
\end{tabular}

105 Eben Weitzman, "Software and Qualitative Research," in Handbook of Qualitative Research, 2nd ed., eds. Norman K. Denizin and Yvonna S. Lincoln (Thousand Oaks: Sage, 2000), 803-820.

106 See H. Bernard Russell et al., Analyzing Qualitative Data, 2nd edition (Thousand Oaks: Sage, 2016), 335-356; Gery W. Ryan and H. Russell Bernard, "Data Management and Analysis Methods," in Handbook of Qualitative Research, 2nd ed., eds. Norman K. Denzin and Yvonna S. Lincoln (Thousand Oaks, CA: Sage, 2000), 769-802.

107 Verdeja, Political Science, 309-311.

108 Ibid. 
Table 2. Proxy Variables, Intended Targets of the Violence

\begin{tabular}{|c|c|c|c|}
\hline & Intended Target & $\begin{array}{l}\text { Proxy Variable: } \\
\text { Logistics of Violence }\end{array}$ & $\begin{array}{l}\text { Proxy Variable: Pursuit of } \\
\text { Victims }\end{array}$ \\
\hline GENOCIDE & $\begin{array}{l}\text { - Unqualified } \\
\text { Group Selection }\end{array}$ & $\begin{array}{l}\text { - Coordinated and } \\
\text { Systematic } \\
\text { - Not ad hoc }\end{array}$ & $\begin{array}{l}\text { - Pursuit (even when } \\
\text { inconvenient) over time } \\
\text { and across distance. }\end{array}$ \\
\hline $\begin{array}{l}\text { MASS } \\
\text { DIRECTED } \\
\text { VIOLENCE }\end{array}$ & $\begin{array}{l}\text { - Qualified } \\
\text { Group Selection }\end{array}$ & $\begin{array}{l}\text { - Possibly coordinated } \\
\text { and systematic } \\
\text { - Possibly ad hoc }\end{array}$ & $\begin{array}{l}\text { - Little to no pursuit } \\
\text { across time-killing may } \\
\text { take place in single } \\
\text { instance. } \\
\text { - Little to no pursuit } \\
\text { across distance-victims } \\
\text { selected on criteria of } \\
\text { convenience. }\end{array}$ \\
\hline
\end{tabular}

Using MAXQDA, I converted these proxy variables into coding themes and sub-themes (Image 3), recording a total of 207 themes and sub-themes. These themes aided theory development in various ways, either by indicating the presence/absence of a specific proxy or by explicating additional details about the nature of the violence.

Image 3. MAXQDA Codebook for Proxy Variables

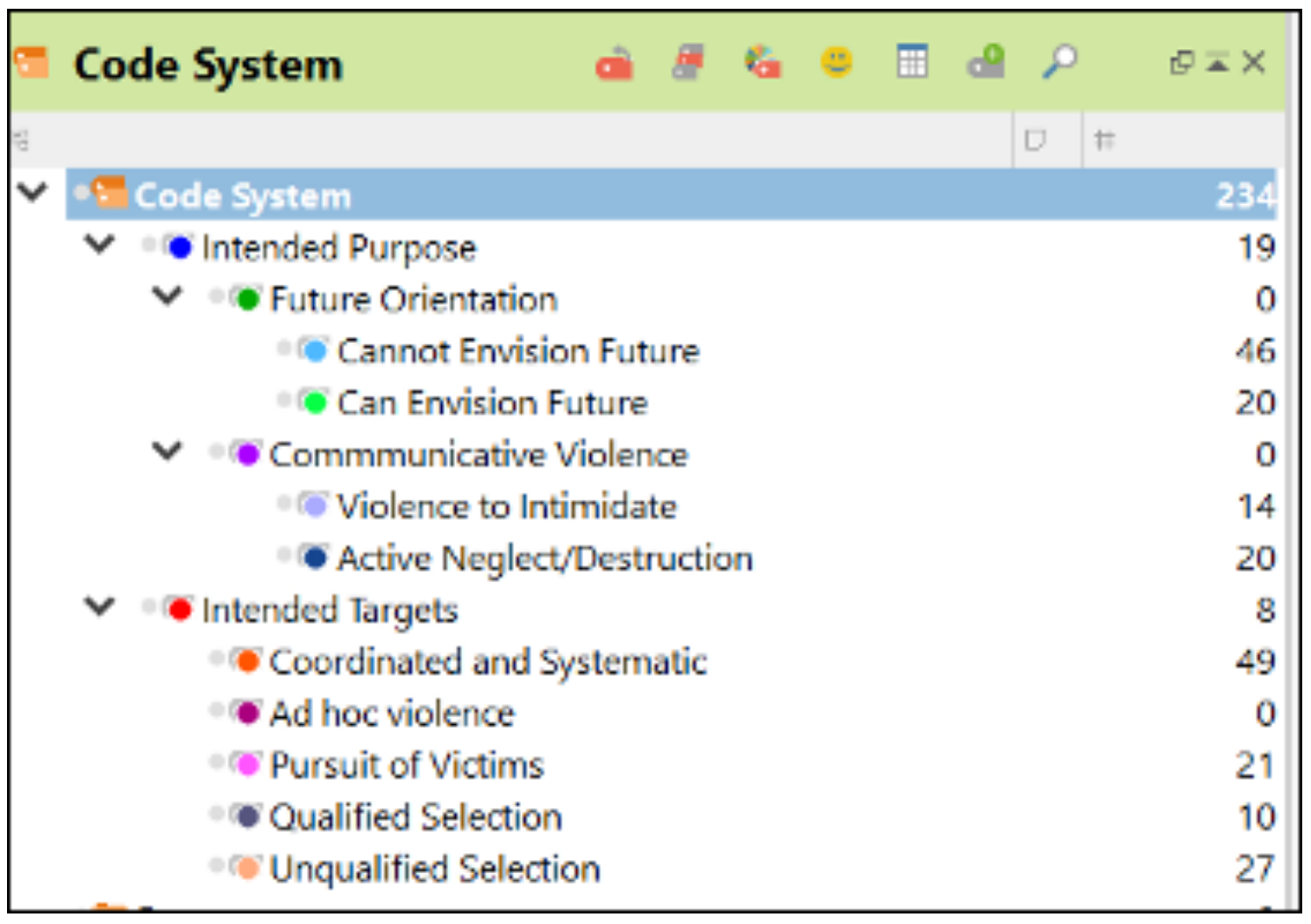

The coded themes were then organized into a letter-by-letter matrix (Table 5) and code relations were assessed (Image 6). To guide readability of the following discussion, Graph 4 contains a preview of the final data by illustrating how the violence dynamics of the Ukrainian Holodomor adhered more closely to a pattern of mass directed violence until an unmistakable trend toward genocidal decision-making began in July 1932. 


\section{Violence Dynamics of the Ukrainian Holodomor: Indications of Genocide or Mass Directed Violence Dynamics}

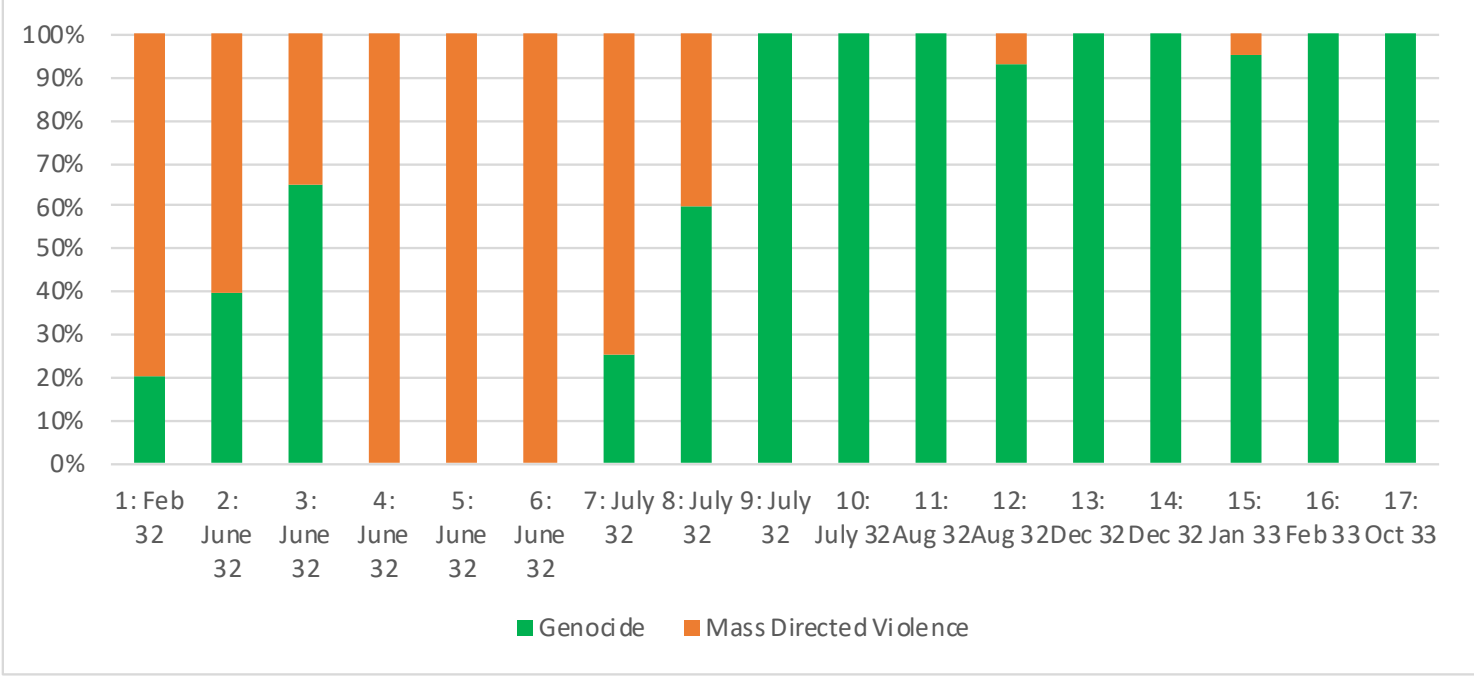

\section{Discussion: Case Study Findings and Results}

Violence Dynamics: February 1932 through July 1932

I begin with a February 10, 1932 letter109 drafted by Komsomol Secretary Pastushenko ${ }^{110}$ of the Polonnyste village, Baban raion (district), Vinnitsa oblast (province) to Stalin. The author writes from the perspective of envisioning the future of Ukraine, albeit one where the Soviet vision for collectivization is more fully realized. He writes approvingly of the village of 317 homesteads being "collectivized one hundred percent," although he views greater Soviet transformation as needed: "No, it's not Soviet but completely bourgeois." 111 Writing from the perspective of a local official, Pastushenko nevertheless depicts an unqualified Ukrainian population that is resisting class transformation. Despite his criticism, his letter indicates his ability to envision the population alive yet more fully controlled in the future with detailed plans to fulfill the Soviet collectivist policies and grain totals. Historian Ruslan Pyrih later noted that this village council head was subsequently relieved of his post and expelled from the communist party after Stalin received this letter. ${ }^{112}$

Next, Grigory Petrovsky, a once prominent Soviet politician who served as Ukraine's prime minister during this period and who fell out of popularity in the late 1930s, ${ }^{113}$ writes to Stalin on June 10, 1932. ${ }^{114}$ This second letter contains six examples of qualified (i.e., differentiated)

\footnotetext{
109 TsDAVO Ukrayiny 1/8/117 (1932), 473-474, in Z. Mychailycenko et al., Kolektyvizatsia i Holod na Ukraini 1929-1933: Zbirnyk Documentiv i Materialiv [Collectivization and Famine in Ukraine 1929-1932: Collection of Documents and Materials] (Kyiv: Naukova Dumka, 1992), 414-416.

110 No first name recorded.

111 TsDAVO Ukrayiny 1/8/117 (1932), 473-474.

112 Pyrih, Holodomor of 1932-1933, 2.

113 Rostyslav Khotin, “Ukraine Tears Down Controversial Statue," BBC, November 26, 2009, accessed September 1, 2019, http:// news.bbc.co.uk/2/hi/europe/8380433.stm.

114 RGASPI 82/2/139 (1932), 162-165, in Yuriy Shapoval and Valeriy Vasyliev, Komandyry Velykoho Holodu: Poyizdky V. Molotova i L. Kaganovicha v Ukrainu i na Pivnichnyi Kavkaz 1932-1933 [Commanders of the Great Famine: V. Molotov and L. Kaganovich, Trips to Ukraine and the Northern Caucasus] (Kyiv: Heneza, 2001), 212-215.
} 
references to the Ukrainian populace, distinguishing between Ukrainian communists and Ukrainian villagers and between "poor peasants and even the middle-class farmers against our class enemies." 115 This type of qualified references between "good" and "bad" Ukrainians exhibits differentiated victim selection (associated with mass directed violence); Petrovsky appears to view some of the population as worth sparing and incorporating into the transformed Soviet society. His letter contains ten examples of envisioning a future, with references to building socialism's popularity and food aid request for starvation victims. Significantly, his letter hints at escalating violence patterns, including two references to unqualified victims of starvation along gender (men and women) and class lines (poor and middle-class farmers). References exist to the highly coordinated policies deepening the suffering and six references to active neglect by the authorities who knew the populations were dying, including Petrovsky's town meeting summary where the population asked, "Why did they [the authorities] create an artificial famine? After all, we had a harvest." 116 Overall, Petrovsky's letter portrays accelerating suffering but depicts some elements of the Ukrainian population as able to provide valuable labor for the Soviet Union's future. The third letter ${ }^{117}$ analyzed was also drafted on June 10, 1932 by Vlas Chubar, ${ }^{118}$ a Ukrainian Bolshevik revolutionary-turned-Soviet politician (the most senior Communist Party official in Ukraine at the time) executed during the Great Terror. In 2010, a Ukrainian criminal court judged Chubar as among the officials personally responsible for the Holodomor's organization, along with Stalin, Molotov, and another figure in this analysis, Lazar Kaganovich. ${ }^{119}$ Chubar's letter includes two references to a qualified view of Ukrainians (i.e., distinguishing between collectivized farmers and those resisting) and six instances of violence used to intimidate (e.g., the "malicious humiliation of private farmers" 120 to harass independent landowners), all indicating mass directed violence dynamics. Chubar also notes the unqualified victim impacts, one reference to the pursuit of victims, nine references to the actively destructive famine impact, and two instances hinting at a future without Ukrainians, blurring the line between the treatment of non-resistors and resistors to collectivization.

Kaganovich, Stalin's close associate and an administrator tasked with implementing collectivization in Ukraine, ${ }^{121}$ forwarded both June 10 letters to Stalin with his comments on June 12, 1932 (letter four). ${ }^{122}$ Indicating that "we will have to provide help [food aid]" although "the question is one of scale," 123 Kaganovich envisions a future for Ukrainian famine survivors. His letter qualifies group selection, distinguishing between resisting Ukrainian peasants and Ukrainian party leadership. ${ }^{124}$ Both proxies indicate mass directed violence dynamics, as does Stalin's response back to Kaganovich in the fifth letter ${ }^{125}$ assessed, dated June 15, 1932. In between invectives against Chubar and Petrovsky, Stalin indirectly concedes Kaganovich's

\footnotetext{
115 Ibid.

116 Ibid.

117 RGASPI 82 / 2 / 139 (1932), 144-153, in Shapoval and Vasyliev, Commanders Great Famine, 206-212.

118 Shapoval and Olynyk, Holodomor: Prologue, 101.

119 Justice v. Skavronik, Ruling in the Name of Ukraine, 13 January 2010, Kyiv Court of Appeals, Criminal Division, trans. Holodomor Victims Memorial, accessed September 2, 2019, https://holodomormuseum.org.ua/en/resolution-ofthe-court/.

120 RGASPI 82/2/139 (1932), 144-153, in Shapoval and Vasyliev, Commanders Great Famine, 206-212.

${ }^{121}$ Ibid.

122 RGASPI 558/11/740 (1932), 41 in Edward Rees et al., eds., Stalin i Kaganovich: Perepyska 1931-1936 [Stalin and Kaganovich: Correspondence 1931-1936] (Moscow: Rosspen, 2001), 164.

123 Ibid.

124 While this analysis focuses on letters written to/from Stalin, other records add contextual detail, portraying an atmosphere in which food assistance was prioritized to revitalize needed laborers and later, to reward the politically loyal who were still able to work. For other records outside this article's methodological criteria, see Klid and Motyl, Holodomor Reader, 257-262.

125 RGASPI 81/3/99 (1932), 63 in Manning et al., Tragedy Soviet Countryside, 169.
} 
vision of a future that includes Ukrainians by agreeing to send aid. At 522,000 poods, ${ }^{126}$ the food aid authorized by Stalin to Ukraine is ultimately one-third of the 1.5 million poods requested, but nevertheless indicates away from total genocidal destruction at this point. Stalin's intention to inflict suffering on the Ukrainian population through limited aid is clear from his statement, "[i]n my opinion, Ukraine has been given more than enough." 127 With this comment following his officials' reports of mass starvation, coupled with Stalin's refusal to halt grain requisitions, this statement was coded as violence to intimidate the population.

Kaganovich's response to Stalin on June 16, 1932 (letter six)128 continues envisioning a future that includes Ukrainians, referencing their subdued-but-useful status as harvesters for the collective grain quotas twice. Explicitly recognizing that the upcoming "harvest campaign will be especially difficult, particularly in Ukraine" and the "danger of premature, spontaneous and unorganized...plundering," Kaganovich advocates for violence to repress by recommending that the party mobilize to prevent this outcome.129 The seventh letter, a response from Stalin to Kaganovich and Molotov on July 2, 1932,130 includes his instructions to attend the upcoming Ukrainian conference of communist leaders and "use all measure to win over workers' sentiment, isolate whining and rotten diplomats (regardless of personas!) and ensure a trulyBolshevik decision" is made. Although Stalin still sees the Ukrainian population as composed of "good" and "bad" Ukrainians (i.e., qualified group selection), he appears to envision a future in which Ukraine is "lost." He writes, "Pay more serious attention to Ukraine... [Chubar and Stanislav Kosior's] rotten diplomacy and criminally-reckless approach to affairs will lose Ukraine in the end." 131 This response marks the first hint of Stalin's emerging zero-sum thinking and hardening view of the Ukrainian/Soviet distinction (see earlier discussion), although at this stage he targets subduing the population through repressive violence like leadership isolation and removal.

Molotov and Kaganovich write Stalin twice on July 6, 1932. First, they report (letter eight) ${ }^{132}$ on the repressive steps they took to subdue increasing intractable local Ukrainian communists, referencing a future with subdued Ukrainian harvesters. For the first time, their letters contain unqualified views of the troublesome Ukrainian population; the local communists have clearly fallen out of favor. They also advocate for increasingly systemized, coordinated collectivization plans, in spite of escalating starvation deaths. Their second telegram (letter nine) ${ }^{133}$ has increasingly unqualified - and unsatisfied-views of the Ukrainian population and the local leaderships' "shortcomings." They reference the ongoing famine's "grave conditions" but recommend to Stalin that the Soviet elites "maintain a reserved tone...to avoid feeding the foreign press." 134 This overt, active neglect of the accelerating starvation fatalities suggests willful choices to allow mass destruction of the Ukrainian people under Soviet jurisdiction. Stalin's short response (letter ten) on July 15, 1932 references a flurry of leadership changes to grasp control. 135 This cleaning house process indicates the growing degree of direct systematic and coordinated control of Ukraine, although no indication exists that greater control was used to alleviate the escalating famine-related fatality rates.

\footnotetext{
${ }^{126}$ Equal to 16.38 kilograms (36.11 pounds).

127 RGASPI 81/3/99 (1932), 63 in Manning et al., Tragedy Soviet Countryside, 169.

128 RGASPI 558/11/740 (1932), 61 in Rees et al., Stalin and Kaganovich, 173.

129 Ibid.

130 RGASPI 558/11/740 (1932), 41 in Rees et al., Stalin and Kaganovich, 164.

${ }^{131}$ Ibid.

132 RGASPI 558/11/78 (1932), 16 in Rees et al., Stalin and Kaganovich, 219.

133 RGASPI 558/11 / 78 (1932), 12 in Rees et al., Stalin and Kaganovich, 218-219.

134 Ibid.

135 RGASPI 81/3/99 (1932), 171 in Rees et al., Stalin and Kaganovich, 225.
} 
Violence Dynamics: August 1932 through October 1933

Around August 1932, this methodology flags abrupt upticks in genocidal proxy variables. On August 11, 1932, Stalin's writing (letter eleven) drops all differentiated references to various "good" or "bad" elements in Ukrainian society, replaced by seven unqualified descriptions of the populace. ${ }^{136}$ Stalin's usage of the word "Ukraine" itself takes on a new collective tone; individualized references to various groups no longer appear. He suggests an upcoming "battle with the counterrevolution in such a large and distinct republic as Ukraine," initiating a framing of the entire republic of Ukraine as an opposing collective, while stating that Ukraine is a "unique republic"137 in his Soviet empire. Six examples of imagining a future without Ukraine were coded in this letter, including "if we do not correct the situation in Ukraine immediately, we will lose Ukraine."138 Stalin further instructs Kaganovich, "Set yourself the goal of turning Ukraine into a fortress of the USSR, a real model republic, within the shortest possible time. Don't spare money for this purpose. Without these and similar measures (economic and political strengthening of Ukraine starting with the raions [districts] along the border, etc.), I repeat once again: we will lose Ukraine."139 Other genocidal proxy variables coded in this letter include six instances of Stalin's growing systematic and coordinated control over Ukraine and three instances categorized as active neglect/willful destruction of the famine's now-catastrophic impact on the Ukrainian population.

Kaganovich's August 16, 1932 response (letter twelve) includes two direct references to envisioning a future without Ukrainians. ${ }^{140}$ He suggests bringing "other workers, fresh blood...for Ukraine,"141 referring to the soon-initiated massive resettlement program that brought Russians, Belarussians, and other Soviet citizens into Ukrainian territories. ${ }^{142}$ Kaganovich twice references increasing coordination and systemization and ten unqualified, negative references to the Ukrainian character. He complains, "Truth be told, the people [Ukrainians] are not the same; I previously knew them to be different; they have gradually changed for the worse, in other words, changed considerably as a result of 'softness' and 'lightness of management.'"143 The once-differentiated Ukrainian communists are termed "bacteria eating away"144 at the Party's leadership. In this letter, he views even Ukrainian communists as threatening unified Soviet rule, hinting at the Ukrainian/Soviet distinction explained elsewhere. Perhaps reflecting Stalin's similar tonal shift, genocidal proxy variables increase.

The thirteenth surviving letter picks up with Kaganovich writing to Stalin on December 22, 1932. ${ }^{145}$ He shares news of increased coordination and systemization of the upcoming grain procurement plan, which proved deadly. Seven references to a future without Ukrainians appear, the majority related to seizures of seed and grain reserves. Kaganovich argues, "We are convinced that this 'preoccupation' with reserves, including seed reserves is seriously hampering and undermining the entire grain procurement plan."146 With the government's knowledge of the mass deaths, ${ }^{147}$ Kaganovich's request to take the reserves-the agricultural

\footnotetext{
136 RGASPI 81/3/99 (1932), 146-151 in Rees et al., Stalin and Kaganovich, 273-274.

137 Ibid.

138 Ibid.

139 Ibid.

140 RGASPI 558/11/740 (1932), 155-159 in Rees et al., Stalin and Kaganovich, 283-284.

141 Ibid.

142 Klid and Motyl, Holodomor Reader, 262; Hennadii Yefimenko, "Resettlement and Deportation in the Post-Famine Years (1933-1936): A District-by-District Breakdown," in Problems of Ukrainian History: Facts, Judgements, Searches (Kyiv: Institute of History of Ukraine, 2013), 136-158, accessed August 19, 2019, https://holodomor.ca/wp-content/ uploads/2020/04/Yefimenko TranslatedArticle.pdf.

143 RGASPI 558/11/740 (1932), 155-159 in Rees et al., Stalin and Kaganovich, 283-284.

144 Ibid.

145 RGASPI 81/3/232 (1932), 62 in Shapoval and Vasyliev, Commanders Great Famine, 335.

146 Ibid.

147 Applebaum, Red Famine, 222-240.
} 
foundation of next year's harvest-strongly indicates that a future with empty, populationdepleted lands was an intentional Soviet policy choice. A week later, on December 29, 1932, the OGPU, the Soviet Union's secret police, issued a report to Stalin on the success of village deportations (letter fourteen).148 As gulag ${ }^{149}$ organizers, OGPU involvement indicates heightened systemization for dealing with Ukrainians, including in the Kuban region. Documentation of several thousand families deported to the harsh Ural Mountains (often an indirect death sentence) indicate a Soviet future with Ukrainians removed, not simply subdued.

Famine conditions deteriorated, indicated by Stalin's January 22, 1933 order (letter fifteen) to prevent the escape of "mass flight of peasants 'for bread.'"150 The inconvenient pursuit of victims is significant for indicating genocidal dynamics (i.e., the victims' unpursued flight would have satisfied the repressive goal of mass directed violence). Genocide's unqualified, destructive logic necessitates that victims be hunted, caught, and destroyed, a pattern emerging in this document. ${ }^{151}$ As fleeing Ukrainian peasants were captured and forcibly returned, soldiers sealed their villages to inflict quick mass casualty rates. ${ }^{152}$ Nine reference indicating a future vision in which Ukrainians no longer exist were recorded in this document, 153 as Ukrainian starvation-driven out-migration was sabotaged and prevented. Four systematic coordination proxy variables indicate extensive pre-planning of the mass killings.

On February 2, 1933, a sixteenth letter 154 is authored by Generikh Yagoda, soon after promoted to NKVD (Soviet intelligence and security agency) chief due to his efficient management of the "Ukraine situation." 155 Yagoda informs Stalin of success in "preventing the mass exodus of villagers from the Ukrainian SSR [Soviet Socialist Republic]"156 as well as the Northern Caucasus and Belarussian SSR, where many Ukrainian population clusters were located. Thirteen instances of highly systematic coordination and ten references to a future without Ukrainians are coded. Fourteen references indicate the far-reaching pursuit of victims, including "organized cordons and search groups on the following roadways: N. Caucasus, Ukraine, South-Eastern Western, Ryazan, Ural, Zlatoustovk, Oktiabrsk, Moscow-Kazan, MoscowBelarus-Baltic." 157 The militarized prevention of famine-driven Ukrainian out-migration, forced repatriation, and village confinements until the victims starved to death ${ }^{158}$ are major factors in the story of the Holodomor and the evidentiary case for genocide.

The seventeenth and final letter 159 in this analysis offers a tragic post-script to Yagoda's report. Eight months later on October 2, 1933, Kaganovich updates Stalin on the "resettlement committee for 1933."160 With Ukrainian lands now experiencing widespread depopulation to famine fatalities, Stalin resettles "15,000 to 20,000 families [from Russia, Belarus, and other Soviet lands] to Ukraine's Steppe."161 While Ukrainian famine victims' petitions for grain aid were repeatedly denied or lessened by Stalin, these new, non-Ukrainian settlers were the

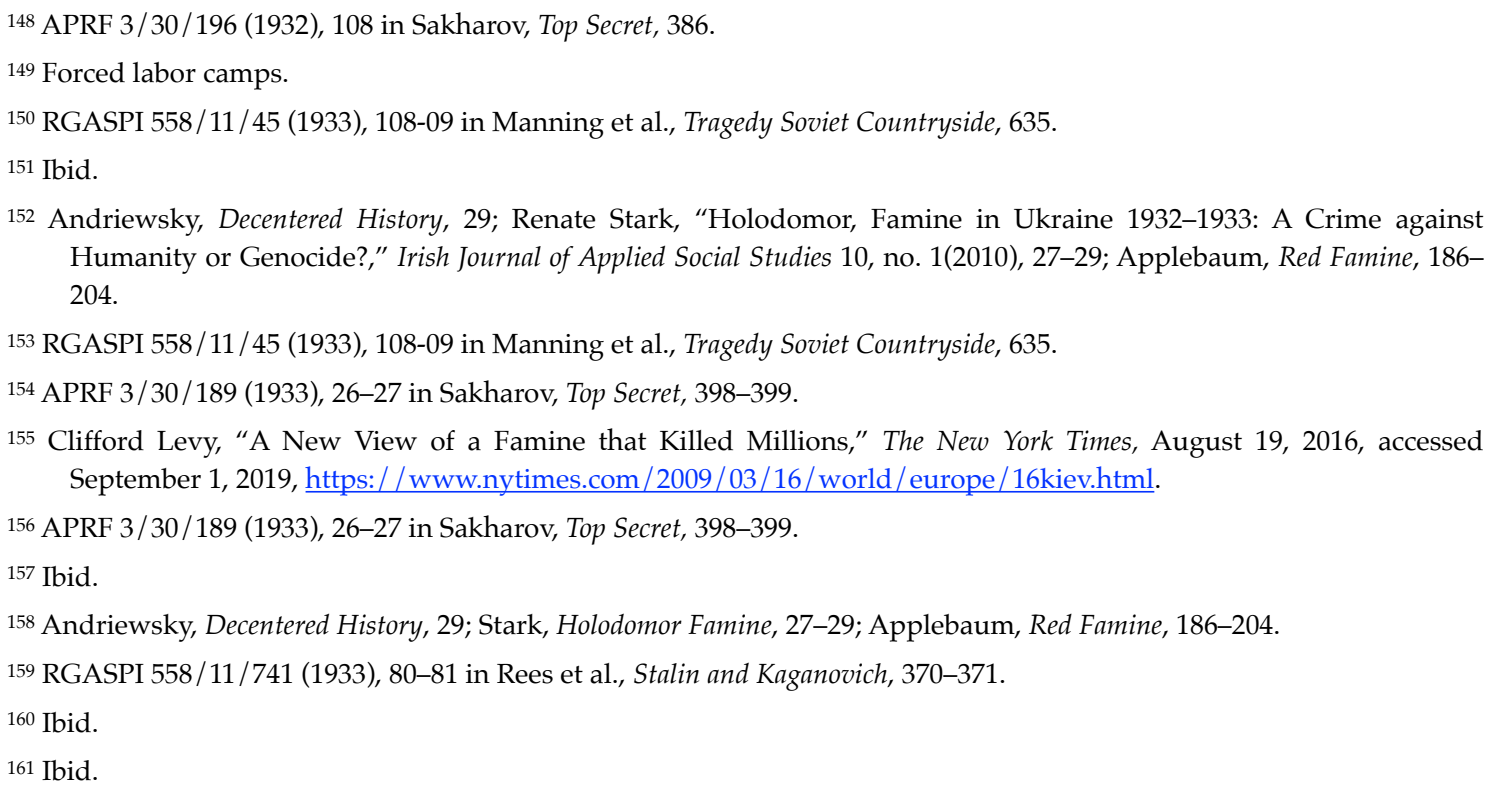


beneficiaries of a centralized campaign that prepared for them by "organiz[ing] house and all necessary equipment...and secur[ing] food." 162 This document adds to other documentation that indicates the Soviet government singled out Ukraine by not providing the same food aid as their neighbors. 163

Implications for Theory and Further Testing

Kaganovich's October 1933 letter to Stalin is the last available document for this analysis, although starvation and resettlement waves of other Soviet citizens into Ukrainian lands continued for several more years before World War II's outbreak. ${ }^{164}$ Although covering a short time period-February 1932 to October 1933-an intriguing pattern emerges in the coded data. Table 5 shows the 207 themes organized in a letter-by-letter matrix according to genocidal or mass directed violence patterns.

Table 5. Letter-by-Letter Matrix with Number of Proxy Variable Appearances, Organized by Violent Phenomena

\begin{tabular}{|c|c|c|c|c|c|c|c|c|c|}
\hline & \multicolumn{5}{|c|}{ GENOCIDE } & \multicolumn{4}{|c|}{$\begin{array}{l}\text { MASS DIRECTED } \\
\text { VIOLENCE }\end{array}$} \\
\hline $\begin{array}{l}\text { Letter \# } \\
\text { (Date) } \\
\text { Author }\end{array}$ & \begin{tabular}{|l} 
Cannot \\
Envision \\
Future \\
\end{tabular} & \begin{tabular}{|c|} 
Active \\
Neglect/ \\
Destruction
\end{tabular} & $\begin{array}{c}\text { Highly } \\
\begin{array}{c}\text { Coordinated, } \\
\text { Systematic }\end{array}\end{array}$ & \begin{tabular}{|l} 
Pursuit \\
of \\
Victims
\end{tabular} & $\begin{array}{l}\text { Unqualified } \\
\text { Victim } \\
\text { Descriptors }\end{array}$ & \begin{tabular}{|c|} 
Can \\
Envision \\
Future \\
\end{tabular} & \begin{tabular}{|c|} 
Violence \\
to \\
Intimidate
\end{tabular} & \begin{tabular}{|l|} 
Ad hoc \\
Violence
\end{tabular} & \begin{tabular}{|l} 
Qualififed \\
Group \\
Selection
\end{tabular} \\
\hline $\begin{array}{c}1 \\
\text { (2/10/32) } \\
\text { Pastushenko }\end{array}$ & - & - & - & - & 1 & 4 & - & - & - \\
\hline $\begin{array}{c}2 \\
2 \\
\text { (6/10/32) } \\
\text { Petrovsky }\end{array}$ & 1 & 6 & 3 & - & 2 & 10 & 2 & - & 6 \\
\hline $\begin{array}{c}3 \\
(6 / 10 / 32) \\
\text { Chubar } \\
\end{array}$ & 2 & 9 & $\cdot$ & 1 & 3 & $\cdot$ & 6 & - & 2 \\
\hline $\begin{array}{c}4 \\
(6 / 12 / 32) \\
\text { Kaganovich }\end{array}$ & - & - & - & - & $\cdot$ & 1 & - & - & 1 \\
\hline $\begin{array}{c}5 \\
(6 / 15 / 32) \\
\text { Stalin } \\
\end{array}$ & - & - & - & $\cdot$ & $\cdot$ & 1 & 1 & - & - \\
\hline $\begin{array}{c}6 \\
(6 / 16 / 32) \\
\text { Kaganovich }\end{array}$ & - & - & - & - & - & 2 & 1 & - & - \\
\hline $\begin{array}{c}7 \\
(7 / 2 / 32) \\
\text { Stalin }\end{array}$ & 1 & - & - & - & - & 1 & 1 & - & 1 \\
\hline $\begin{array}{c}8 \\
\text { (7/6/32) } \\
\text { Molotov \& } \\
\text { Kaganovich } \\
\end{array}$ & - & - & 2 & - & 1 & 1 & 1 & - & - \\
\hline $\begin{array}{c}9 \\
\text { (7/6/32) } \\
\text { Molotov } \\
\text { and } \\
\text { Kaganovich } \\
\end{array}$ & - & 2 & - & - & 1 & - & - & - & - \\
\hline $\begin{array}{c}10 \\
(7 / 15 / 32) \\
\text { Stalin }\end{array}$ & - & - & 4 & - & - & - & - & - & - \\
\hline $\begin{array}{c}11 \\
(8 / 11 / 32) \\
\text { Stalin }\end{array}$ & 6 & 3 & 6 & - & 7 & - & - & - & - \\
\hline $\begin{array}{c}12 \\
\text { (8/16/32) } \\
\text { Kaganovich }\end{array}$ & 2 & - & 2 & - & 10 & - & 1 & - & - \\
\hline $\begin{array}{c}13 \\
(12 / 22 / 32) \\
\text { Kaganovich }\end{array}$ & 7 & - & 1 & - & - & - & - & - & - \\
\hline $\begin{array}{c}14 \\
(12 / 29 / 32) \\
O G P U\end{array}$ & 2 & - & 2 & - & - & - & - & - & - \\
\hline $\begin{array}{c}15 \\
(1 / 22 / 33) \\
\text { Stalin } \\
\end{array}$ & 9 & - & 4 & 6 & - & - & 1 & - & - \\
\hline $\begin{array}{c}16 \\
(2 / 2 / 33) \\
\text { Yagoda }\end{array}$ & 10 & - & 13 & 14 & 2 & - & - & - & - \\
\hline $\begin{array}{c}17 \\
\text { (10/2/33) } \\
\text { Kaganovich } \\
\end{array}$ & 6 & - & 12 & - & - & - & - & - & - \\
\hline
\end{tabular}

Color Code: Intended Purpose Proxies / Intended Targets Proxies

\footnotetext{
162 Ibid.

163 Klid and Motyl, Holodomor Reader, 67-68.

164 Liber, Total Wars, 196-201.
} 
With the data organized (see also Graph 4), mass directed violence clusters (e.g., envisioned futures with Ukrainian existence, violence to repress and subdue) appear in nearly each of the first eight letters, i.e., until July 6, 1932. Each of the ten total references to "qualified group selection" appear during this time window. Some scattered proxy indicators for genocide appear; however, they are isolated to the missives by Stalin's subordinates, Petrovsky and Chubar. Falling mainly in the "active neglect/destruction" category, potential explanations include their positionality and potential desire to impress Stalin through tough-sounding language. In context, they are describing the Holodomor's ongoing destructive toll but are requesting food aid from Stalin. While actively neglectful and dismissive of mass suffering, the larger context hints that radicalized genocidal intentionality may not accurately characterize their behavior or discourse at this stage. According to the data, a stronger case for genocidal dynamics materializes around the timing of Stalin's August 11, 1932 letter. ${ }^{165}$ Often cited in Holodomor genocide evaluations, my analysis further contextualizes this letter with proxy variable coding suggesting that this letter was connected to broader shifts in Stalin's decisionmaking and trends strengthened by his close associates. After this letter, mass directed violence proxy variables abruptly drop off. Significant on its own, it is also striking that genocidal proxy variables surge in quantity at this historical moment, illustrated by a clean break around letter eleven. 166 Historiographies add nuance and additional explanations to these patterns. The minutes of two Party conference meetings have been analyzed, with some historians suggesting Moscow-based policy decision-making between July 1932 and February 1933 worsened famine dynamics as a tool to destroy Kharkiv (eastern Ukraine) as a sub-center of power. ${ }^{167}$ Relatedly, Graziosi has discussed changes in enforcing procurement and related harvest spikes which contextualize the patterns I suggest. 168 Finally, variations in unqualified or qualified descriptors raise important questions about center/periphery relations, imperial-colonial undertones, and the potential diversity of perspectives and policy choices among Union and republic authorities. 169

Finally, using MAXQDA code relations processing, I explored theme relationships. Each significant code relation flagged (Image 6) constitute genocide-to-genocide proxy variable clustering or mass directed violence theme clustering (square size visually depicts the numbers cited here). Perhaps due to its extreme nature, the most significant relations existed between genocide proxies. In particular, a relationship was noted between "cannot envision a future" [Cann] (intended purpose) to "coordinated and systemized" [Coor] (intended target) violence; these variables co-occurred together 31 times. Lesser relationships were noted between "cannot envision a future" (intended purpose) and "unqualified group selection" [Unqu] (intended target), which co-occurred 17 times, as well as between "cannot envision a future" (intended purpose) and "pursuit of victims" [Pursui] (intended target), which co-occurred 19 times. "Ad

165 RGASPI 81/3/99 (1932), 146-151 in Rees et al., Stalin and Kaganovich, 273-274.

166 Ibid.

167 Kulchytsky, Famine 1932-1933, 7, 29; Shapoval and Vasyliev, Commanders Great Famine, 57; Daria Mattingly, "Idle, Drunk and Good-for-Nothing:' The Rank-and-File Perpetrators of 1932-1933 Famine in Ukraine and Their Representation in Cultural Memory," (PhD diss., University of Cambridge, 2018), 18-79, accessed August 19, 2019, https://doi.org/10.17863/CAM.38324.

168 Graziosi, Soviet Famines, 102-104.

169 In addition to center/periphery dynamics, debate continues over whether the Soviet Union's internal dynamics are best labeled "imperial" or "colonial." This dispute does not obscure power differentials that are important to discussions of genocide. An imperial-colonial prism contextualizes Soviet Ukraine's economic exploitation as linked to wider industrialization efforts as well as intensifying repressions of collectivization resistance and/or nationalist sentiment. A full summary of this discussion is beyond this article's scope, but examples of power differentials linked to center/periphery and imperial-colonial dynamics may exist in the supplicatory tones taken by Petrovsky and Chubar (both ethnic Ukrainians and members of the Politburo of the Communist Party of Ukraine, akin to a regional unit of the All-Union Communist Party) and in Stalin's response on August 11, 1932. The formers' request for food aid hints at repressive colonial administrators appealing to a sovereign imperial ruler, a factor that may elucidate motivations and that underscores the contrast of Stalin's destruction-oriented response. 
hoc violence" (mass directed violence) does not appear in any letter; however, it is not certain that small-scale, lower-level instances would have been raised to the highest leadership levels of the Soviet Union.

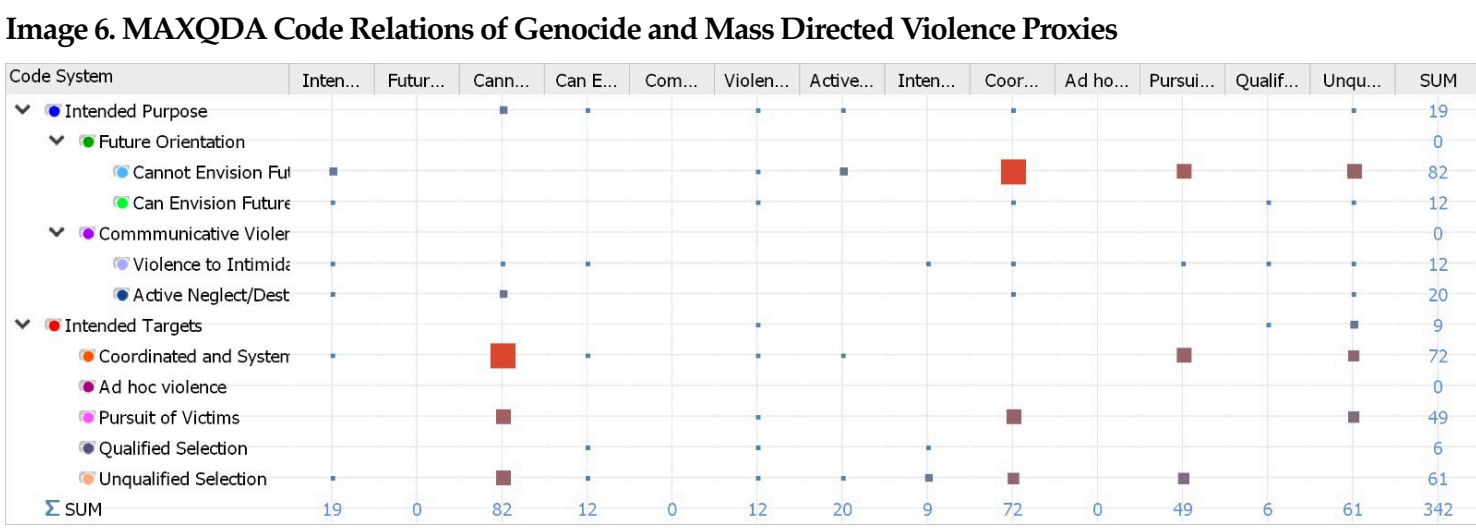

Subject to additional testing, my approach yielded results that confirm the significance of a framework that distinguishes between genocides and mass directed violence according to the intended purpose and target characteristics suggested by other scholars. ${ }^{170}$ Proxy variable clustering indicates the promise of this empirical approach and the potential to apply it to other cases in diverse geographic contexts, historical and contemporary. As referenced, additional analyses, including automated algorithm-based studies, could widen the scope of analysis. Still, both research questions posed indicate affirmative answers. First, the records surveyed, centered on Joseph Stalin, support analytic assessments of the Holodomor as a genocide beginning around July to August 1932 as assessed according to intended targets and intended purposes. Second, Holodomor violence does shift across the conceptual boundaries of genocide. This finding - that specific dynamics-based patterns can be micro-mapped within the broader chronological context-illustrates empirical sensitivity and demonstrates a dynamics-based now-casting approach to tracing complex violence in real-time. The brunt of Holodomor deaths occurred in an exceedingly compressed timeframe, yet this short timeframe still allowed for the violence to morph in pattern and form. Taken alone, numerical victim assessments may have missed this pattern shift, an omission with negative implications for intervention activities that are best tailored to specific dynamics and initiated at a precise ripe moment.

\section{Conclusion}

This analysis has demonstrated a way to operationalize existing literature that calls for genocides to be traced as a process and a phenomenon that can be distinguished from other forms of large-scale violence. ${ }^{171}$ Definitional quagmires once incentivized primarily quantitative approaches to many forms of large-scale violence. While helpful for certain questions, this article supports new calls for a third type of genocide policy-relevant monitoring tool, nowcasting, that draws from mixed qualitative and quantitative approaches. ${ }^{172}$ Grounded in the view that large-scale violence can be diagnosed according to its presenting symptomsincluding as these patterns change-the Holodomor case illustrates how this approach can more accurately flag evolving trends even within a compressed time period. Consequently, this approach can foster more carefully calibrated preventive responses by identifying additional nuances in violence dynamics, perpetrator decision-making, and possible spectrums of

\footnotetext{
170 Straus, Destroy Them, 552-553.

171 Ibid., 551-555; Verdeja, Political Science, 311-313.

172 Heldt, Atrocity Crimes, 53-59; Tetlock, Second Thoughts, 470.
} 
outcomes. While the conceptual seeds of this approach sprouted ten years ago, ${ }^{173}$ I have outlined a new methodology to operationalize this theorizing. Analyzing the historical Holodomor case through this methodological lens resulted in affirmative answers to the posed research questions and a clustering of proxy variables. It also empirically demonstrated the emergence of a key change in the Holodomor's violence dynamics, a shift also supported by historical approaches. This article's proxy variables coding approach was able to triangulate violence shifts by organizing and highlighting major patterns during precise historical moments. As this methodology and accompanying proxy variables can be translated into algorithms, increased speed for tracing the day-by-day process of violence and pinpointing major pattern shifts over periods of time is possible.

Several additional implications follow. Ultimately, the empirical approach I took concurs with other academics ${ }^{174}$ who have labeled the Holodomor a genocide, thus underscoring this case's importance to the comparative genocide studies field. More tightly focused than longer-view historiographies or legal analyses, I nevertheless reach a concurring conclusion. In addition, while the Holodomor occurred nearly 100 years ago, the conceptual and methodological approach I took in this analysis can be applied to ongoing, contemporary acts of mass killing. Building on this reality, specific policy proposals that are tailored to genocidal or mass directed violence patterns are needed. Just as different pharmaceutical remedies are needed for diverse pathologies, our field must also tailor its prevention policy recommendations and toolkits for diverse manifestations of large-scale violence.

\section{Bibliography}

Andriewsky, Olga. "Toward a Decentered History: The Study of the Holodomor and Ukrainian Historiography." In Contextualizing the Holodomor: The Impact of Thirty Years of Ukrainian Famine Studies, edited by Andrij Makuch and Frank Sysyn, 14-48. Edmonton, Toronto: Canadian Institute of Ukrainian Studies, 2015.

Antonovych, Myroslava. "Legal Accountability for the Holodomor-Genocide of 1932-1933 (Great Famine) in Ukraine." Kyiv-Mohyla Law and Politics Journal 1, no. 1 (2015), 159-176.

Applebaum, Anne. Red Famine: Stalin's War on Ukraine. New York: Knopf Doubleday Publishing Group, 2017.

Arendt, Hannah. The Origins of Totalitarianism. New York: Harcourt Brace Jovanovich, Inc., [1956] 1973.

Bauman, Zygmunt. Modernity and the Holocaust. New York: Oxford University Press, 1989.

Bellamy, Alex. "Mass Atrocities and Armed Conflict: Links, Distinctions, and Implications for the Responsibility to Protect." Policy Analysis Brief for the Stanley Foundation, February 2011, 1-22. Accessed October 2, 2021. https://stanleycenter.org/publications/ pab/BellamyPAB22011.pdf.

Bernard, H. Russell, Amber Wutich, and Gery W. Ryan. Analyzing Qualitative Data, 2nd ed. Thousand Oaks: Sage, 2016.

Cameron, Sarah. The Hungry Steppe: Famine, Violence, and the Making of Soviet Kazakhstan. Ithaca: Cornell University Press, 2018.

Carynnyk, Marco, Lubomyr Y. Luciuk, and Bohdan S. Kordan, eds. The Foreign Office and the Famine: British Documents on Ukraine and the Great Famine of 1932-1933. Vestal: Limestone Press, 1988.

Chalk, Frank, and Kurt Jonassohn. The History and Sociology of Genocide: Analyses and Case Studies. New Haven: Yale University Press, 1990.

Chirot, Daniel, and Clark McCauley. Why Not Kill Them All? The Logic and Prevention of Mass Political Murder. Princeton: Princeton University Press, 2006.

\footnotetext{
173 Verdeja, Political Science, 316; Straus, Destroy Them, 546-548; Hiebert, Theorizing Destruction, 328-335; Hiebert, Questioning Boundaries, 34-36.

174 Graziosi, Soviet 1931-1933 Famines, 106-109; Werth, Great Ukrainian Famine.; Werth, Crimes Stalin Regime, 406-408, 414-415; Naimark, Stalin's Genocides, 70-79; Klid and Motyl, Holodomor Reader, xlii-xliv; Liber, Total Wars, 192-197.
} 
Cohen, Akiba, Tamar Zemach-Marom, Jurgen Wilke, and Birgit Schenk. The Holocaust and the Press: Nazi War Crime Trials in Germany and Israel. Cresskill, NJ: Hampton, 2002.

Davies, R.W. and Stephen Wheatcroft. The Years of Hunger: Soviet Agriculture, 1931-1933. New York: Palgrave Macmillan, 2004.

Department of Peace and Conflict Research. "Uppsala Conflict Data Program." Uppsala University, Sweden, 2017. http:/ / ucdp.uu.se/.

Devereux, Stephen. "Introduction: From 'Old Famines' to 'New Famines."' In The New Famines: Why Famines Persist in an Era of Globalization, edited by Stephen Devereux, 1-26. New York: Routledge, 2007.

Ellman, Michael. "Stalin and the Soviet Famine of 1932-1933 Revisited." Europe-Asia Studies 59, no. 4 (2007), 663-693.

Fitzpatrick, Sheila. Stalin's Peasants: Resistance and Survival in the Russian Village after Collectivization. New York: Oxford University Press, 1994.

Fujii, Lee Ann. Killing Neighbors: Webs of Violence in Rwanda. Ithaca: Cornell University Press, 2009.

Graziosi, Andrea. "The Soviet 1931-1933 Famines and the Ukrainian Holodomor: Is a New Interpretation Possible, and What Would Its Consequences Be?." Harvard Ukrainian Studies 27, no. 1 (2004), 97-115.

Graziosi, Andrea, Lubomyr A. Hajda, and Halyna Hryn. "Introduction to After the Holodomor: The Enduring Impact of the Great Famine on Ukraine." Harvard Ukrainian Studies 30, no. 1 (2008), xv-xxvii.

Harff, Barbara. "No Lessons Learned from the Holocaust? Assessing Risks of Genocide and Political Mass Murder since 1955." American Political Science Review 97, no. 1 (2003), 5773.

Harvard Ukrainian Research Institute (HURI). "The Great Famine Project." MAPA: Digital Atlas of Ukraine, 2018. http: / /gis.huri.harvard.edu/historical-atlas/the-great-famine.html.

Heldt, Birger. "Atrocity Crimes as a Disease: A Statistical Approach to Early Detection." In Preventing Mass Atrocities: Politics and Practices, edited by Barbara Harff and Ted Gurr, 40-59. New York and Oxford: Routledge, 2019.

Hiebert, Maureen S. "Questioning Boundaries: What's Old and What's New in Comparative Genocide Theory." In Genocide Matters: Ongoing Issues and Emerging Perspectives., edited by Joyce Apsel and Ernesto Verdeja, 321-335. New York: Routledge, 2013.

"Theorizing Destruction: Reflections on the State of Comparative Genocide Theory." Genocide Studies and Prevention 3, no. 3 (2008), 309-339.

Hilberg, Raul. Perpetrators, Victims, Bystanders: The Jewish Catastrophe 1933-1945. New York: Harper Collins, 1992.

. The Destruction of the European Jews. New Haven: Yale University Press, 2003.

Hinton, Alexander Laban. "Critical Genocide Studies." In Genocide Matters: Ongoing Issues and Emerging Perspectives, edited by Joyce Apsel and Ernesto Verdeja, 4-15. London: Routledge, 2013.

Hirsch, Francine. Empire of Nations: Ethnographic Knowledge and the Making of the Soviet Union. Ithaca: Cornell University Press, 2005.

Hochschild, Adam. King Leopold's Ghost: A Story of Greed, Terror, and Heroism in Colonial Africa. New York: Houghton Mifflin Company, 1998.

Hook, Kristina. "Forecasting Policy Trends." Anthropology News, July 13, 2018, accessed January 6, 2019. https:// doi.org/10.1111/AN.907.

-------.. “When the Ukrainian World Was Destroyed': Genocidal Narrative Convergence and Stakeholder Interactions during National Crises." PhD diss., University of Notre Dame, 2020. https://curate.nd.edu/show/jw827943j9c.

Irvin-Erickson, Douglas. Raphaël Lemkin and the Concept of Genocide. Philadelphia: University of Pennsylvania, 2017.

Jones, Adam. Genocide: A Comprehensive Introduction. 3rd ed. New York: Routledge Publishers, 2017. 
Khotin, Rostyslav. “Ukraine Tears Down Controversial Statue." BBC, November 26, 2009. http://news.bbc.co.uk/2/hi/europe/8380433.stm.

Klid, Bohdan, and Alexander J. Motyl, eds. The Holodomor Reader: A Sourcebook on the Famine of 1932-1933 in Ukraine. Toronto: Canadian Institute of Ukrainian Studies, 2012.

Kondrashin, Viktor. "Hunger in 1932-1933: A Tragedy of the Peoples of the USSR." Holodomor Studies 1, no. 2 (2009), 16-21. Accessed August 19, 2019. https://holodomor.ca/wpcontent/uploads / 2016/09/2.-Holodomor-Scholarship-MY.pdf.

Krain, Matthew. "State-Sponsored Mass Murder: The Onset and Severity of Genocides and Politicides." The Journal of Conflict Resolution 41, no. 3 (1997), 331-360.

Kulchytsky, Stanislav. The Famine of 1932-1933 in Ukraine: An Anatomy of the Holodomor. Translated by Ali Kinsella. Toronto: Canadian Institute of Ukrainian Studies, 2018.

"Why Did Stalin Exterminate the Ukrainians? Comprehending the Holodomor: The Position of Soviet Historians, Part 4." The Day Weekly Digest no. 37, November 22, 2005. https://www.usubc.org/AUR/aur621.php\#a4.

Kuromiya, Hiroaki. "The Soviet Famine of 1932-1933 Reconsidered." Europe-Asia Studies 60, no. 4 (2008), 663-675.

Lemkin, Raphaël. Axis Rule in Occupied Europe: Laws of Occupation, Analysis of Government, Proposals for Redress. Washington, DC: Carnegie Endowment for International Peace, Division of International Law, 1944.

Levchuk, Nataliia, Oleh Wolowyna, Omelian Rudnytskyi, Alla Kovbasiuk, and Nataliia Kulyk. "Regional 1932-1933 Famine Losses: A Comparative Analysis of Ukraine and Russia." Nationalities Papers 48, no. 3 (2020), 492-512.

Levy, Clifford. "A New View of a Famine That Killed Millions." The New York Times, August 19, 2016. Accessed September 1, 2019. https://www.nytimes.com/2009/03/16/world/ europe/16kiev.html.

Liber, George. Total Wars and the Making of Ukraine, 1914-1954. Toronto: University of Toronto Press, 2016.

Madley, Benjamin. "Reexamining the American Genocide Debate: Meaning, Historiography, and New Methods." American Historical Review 120, no. 1 (2015), 98-139.

Malpas, Anna. "Between the Lines: Historians Put Stalin-Era Diaries Online." AFP, March 27, 2017. Accessed September 1, 2019. https://sg.news.yahoo.com/between-lineshistorians-put-stalin-era-diaries-online-055626150.html.

Manning, Reginald, V. P. Danilov and Lynne Viola, eds. Tragedia Sovietskoi Derevni: Kolektyvizatsia i Raskulachivanie: Dokumenty i Materialy v Pyati Tomakh [Tragedy of the Soviet Countryside: Collectivization and Dekulakization: Documents and Materials in Five Volumes]. Moscow: Rosspen, 2001.

Martin, Terry. The Affirmative Action Empire: Nations and Nationalism in the Soviet Union, 19231939. Ithaca: Cornell University Press, 2001.

Matiash, Iryna. "Archives in Russia on the Famine in Ukraine." Harriman Review 16, no. 2 (2008), 36-45. Accessed August 19, 2019. https://docplayer.net/48842438-The-harrimanreview-the-holodomor-of-papers-from-the-75th-anniversary-conference-on-theukrainian-famine-genocide.html.

Mattingly, Daria. "'Idle, Drunk and Good-for-Nothing': The Rank-and-File Perpetrators of 19321933 Famine in Ukraine and Their Representation in Cultural Memory." PhD diss., University of Cambridge, 2018. Accessed August 19, 2019. https://doi.org/10.17863/ CAM.38324.

May, Larry. Genocide: A Normative Account. Cambridge: Cambridge University Press, 2010.

McVay, Athanasius D. and Lubomyr Y. Luciuk, eds., The Holy See and the Holodomor: Documents from the Vatican Secret Archives on the Great Famine of 1932-1933 in Soviet Ukraine. Kingston: Kashtan Press, 2011.

Medvedev, Roy A. Let History Judge: The Origins and Consequences of Stalinism. New York: Columbia University Press, 1989. 
Mychailycenko, Z. E. Shatalina and Stanislav Kulchytsky. Kolektyvizatsia i Holod Na Ukraini 1929-1933: Zbirnyk Documentiv i Materialiv [Collectivization and Famine in Ukraine: 19291932: Collection of Documents and Materials]. Kyiv, Ukraine: Naukova Dumka, 1992.

Naimark, Norman M. Stalin's Genocides. Princeton: Princeton University Press, 2010.

--------. "Applebaum, Fitzpatrick, and the Genocide Question." Contemporary European History 27, no. 3 (2018), 435-439.

Nickell, Amber N. "Book Review: The Famine of 1932-1933 in Ukraine: An Anatomy of the Holodomor, by Stanislav Kulchytsky." Canadian Slavonic Papers 61, no. 4 (2019), 457-459

Osiel, Mark. Making Sense of Mass Atrocity. Cambridge: Cambridge University Press, 2009.

Plokhy, Serhii. The Gates of Europe: A History of Ukraine. New York: Basic Books, 2015.

Pyrih, Ruslan. Holodomor of 1932-1933 in Ukraine: Documents and Materials. Translated by Stephan Bandera. Kyiv, Ukraine: National University of Kyiv-Mohyla Press, 2008. Accessed August 19, 2019. http://history.org.ua/LiberUA/PyrihHolodUkr 2008/ PyrihHolodUkr 2008.pdf.

Rees, Edward, Oleg Khlevnyuk, R.W. Davies, Liudmila Kosheleva, and Larisa Rogovaya, eds. Stalin i Kaganovich: Perepyska. 1931-1936 [Stalin and Kaganovich: Correspondence, 19311936]. Moscow: Rosspen, 2001.

Regan, Patrick M. “Quantitative Approaches.” In Routledge Handbook on Peacebuilding, edited by Roger MacGinty, 183-194. London: Routledge, 2013.

Rosenberg, Sheri P, and Everita Silina. "Genocide by Attrition: Slow and Efficient." In Genocide Matters: Ongoing Issues and Emerging Perspectives, edited by Joyce Apsel and Ernesto Verdeja, 116-136. New York: Routledge, 2013.

Rozenas, Arturas, and Yuri M. Zhukov. "Mass Repression and Political Loyalty: Evidence from Stalin's 'Terror by Hunger." American Political Science Review 113, no. 2 (2019), 569-583.

Rudnytskyi, Omelian, Nataliia Levchuk, Oleh Wolowyna, Pavlo Shevchuk, and Alla Kovbasiuk. "Demography of a Man-Made Human Catastrophe: The Case of Massive Famine in Ukraine 1932-1933." Canadian Studies in Population 42, no. 1-2 (2015), 53-80.

Rudolph, Christopher. "Constructing an Atrocities Regime: The Politics of War Crimes Tribunals." International Organization 55, no. 3 (2001), 655-691.

Ryan, Gery W. and H. Russell Bernard. "Data Management and Analysis Methods." In Handbook of Qualitative Research, 2nd ed., edited by Norman K. Denzin and Yvonna S. Lincoln. Thousand Oaks: Sage, 2000.

Sakharov, A. N. "Sovershenno Sekretno": Lubianka - Stalinu o Polozhenii v Strane: V 4 t. ["Top Secret": From Lubianka to Stalin on the State of the Country in 4 Volumes]. Moscow: Institut Rossiiskoi Istorii RAN, 2001.

Schabas, William. Unimaginable Atrocities: Justice, Politics, and Rights at the War Crimes Tribunals. Oxford: Oxford University Press, 2012.

Scrimshaw, Nevin S. “The Phenomenon of Famine." Annual Review of Nutrition 71, no. 1 (1987), $1-21$.

Semotiuk, Andriy. "The Ukrainian Holodomor-Was It Genocide?" Famine-Genocide in Ukraine, 2008, 1-7. Accessed September 1, 2019. https://myworkvisa.com/usa/downloads/ Holodomor.pdf.

Sen, Amartya. Poverty and Famines: An Essay on Entitlement and Deprivation. Oxford: Oxford University Press, 1981.

Serbyn, Roman. "Lemkin on Genocide of Nations." Journal of International Criminal Justice 7, no. 1 (2009), 123-130.

Shapoval, Yuri, and Marta Olynyk. "The Holodomor: A Prologue to Repressions and Terror in Soviet Ukraine." Harvard Ukrainian Studies 30, no. 1 (2008), 99-100.

Shapoval, Yuri, and Valeriy Vasyliev. Komandyry Velykoho Holodu: Poyizdky V. Molotova i L. Kaganovicha v Ukrainu i Na Pivnichnyi Kavkaz: 1932-1933 [Commanders of the Great Famine: V. Molotov and L. Kaganovich, Trips to Ukraine and the Northern Caucasus]. Kyiv, Ukraine: Heneza, 2001. 
Shkandrij, Myroslav, and Olga Bertelsen. “The Soviet Regime's National Operations in Ukraine, 1929-1934." Canadian Slavonic Papers 55, no. 3-4 (2013), 417-447.

Skavronik, Justice V. M. "Ruling in the Name of Ukraine, 13 January 2010." Translated by Holodomor Victims Memorial. Kyiv Court of Appeals, Criminal Division, n.d. https:// holodomormuseum.org.ua/en/resolution-of-the-court/.

Stark, Renate. "Holodomor, Famine in Ukraine 1932-1933: A Crime against Humanity or Genocide?" Irish Journal of Applied Social Studies 10, no. 1 (2010), 20-30.

Straus, Scott. "'Destroy Them to Save Us:' Theories of Genocide and the Logics of Political Violence." Terrorism and Political Violence 24, no. 4 (2012), 544-560.

--------. "Second-Generation Comparative Research on Genocide." World Politics 59, no. 3 (2007), 476-501.

------. The Order of Genocide: Race, Power, and War in Rwanda. Ithaca: Cornell University Press, 2006.

Tetlock, Philip E. "Second Thoughts about Expert Political Judgement: Reply to the Symposium." Critical Review: A Journal of Politics and Society 22, no. 4 (2010), 467-488.

United Nations. General Assembly Resolution 260, Convention on the Prevention and Punishment of the Crime of Genocide. December 9, 1948. UN Doc. A/RES/260(III).

Valentino, Benjamin. Final Solutions: Mass Killing and Genocide in the 20th Century. Ithaca: Cornell University Press, 2004.

Vallin, Jacques, France Mesle, Serguei Adamets, and Serhiy Pyrozhkov. "The Great Famine: Population Losses in Ukraine." In Holodomor Reflections on the Great Famine of 1932-1933 in Soviet Ukraine, edited by Lubomyr Y. Luciuk and Lisa Grekul, 33-46. Kingston, Ontario: Kashtan Press, 2008.

Vasyliev, Valeriy, Nicolas Werth, and Serhii Kokin, eds. Partiyno-Radianske Kerivnytstvo Ukraiinskoii SSR Pid Chas Holodomoru 1932-1933: Vozhdi, Pratsionyky, Actyvisty, Zbirnyk Dokumentiv Ta Materialiv. Kyiv, Ukraine: Institute of Ukrainian History, 2013.

Verdeja, Ernesto. "Predicting Genocide and Mass Atrocities." Genocide Studies and Prevention: An International Journal 9, no. 3 (2016), 13-32.

"The Political Science of Genocide: Outlines of an Emerging Research Agenda." Perspectives on Politics 10, no. 2 (2012), 307-321.

Weitzman, Eben. "Software and Qualitative Research." In Handbook of Qualitative Research, 2nd ed., edited by Norman Denzin and Yvonna Lincoln, 803-820. Thousand Oaks: Sage, 2000.

Werth, Nicolas. "The Crimes of the Stalin Regime: Outline for an Inventory and Classification." In The Historiography of Genocide, edited by Dan Stone, 400-419. New York: Palgrave, 2008.

"The Great Ukrainian Famine of 1932-1933." Mass Violence and Resistance, 2008. Accessed August 20, 2019. https://www.sciencespo.fr/mass-violence-war-massacreresistance/en/document/great-ukrainian-famine-1932-33.

Wolowyna, Oleh. "Comments on the Demographic Consequences of the Holodomor." Harvard Ukrainian Studies 30, no. 1-4 (2008), 243-250.

"Demographic Dimensions of the 1932-33 Famine in Ukraine." In Famine in Ukraine, 1932-1933: Genocide by Other Means, edited by Taras Hunczak and Roman Serbyn, 98114. New York: Shevchenko Scientific Society, 2007.

Wolowyna, Oleh, Nataliia Levchuk, and Alla Kovbasiuk. "Monthly Distribution of 1933 Famine Losses in Soviet Ukraine and the Russia Soviet Republic at the Regional Level." Nationalities Paper 48, no. 3 (2020), 530-548.

Yefimenko, Hennadii. "The Kremlin's Nationality Policy in Ukraine after the Holodomor of 1932-1933." Harvard Ukrainian Studies 30, no. 1 (2008), 69-98.

"Resettlement and Deportation in the Post-Famine Years (1933-1936): A District-byDistrict Breakdown." In Problems of Ukrainian History: Facts, Judgements, Searches, 136158. Kyiv, Ukraine: Institute of History of Ukraine, 2013. Accessed August 19, 2019. https://holodomor.ca/wp-content/uploads/2020/04/Yefimenko TranslatedArticle.pdf. 